\title{
Why the rich always stay rich (no matter what, no matter the cost)
}

\author{
José Gabriel Palma
}

To determine the laws which regulate [the distribution of the produce of the earth between rent, profit and wages] is the principal problem in Political Economy (David Ricardo)

Inequality is a choice [between perfectly feasible alternatives] (Joseph Stiglitz)

I am my choices (Jean-Paul Sartre)

The comfort of the rich depends upon an abundant supply of the poor Voltaire)

\begin{abstract}
This article returns to the Ricardian tradition of understanding income distribution as the outcome of an "antagonistic" conflict with a multiplicity of actors and struggles, where history, politics and institutions matter as much as economic "fundamentals". Because this relates to the political sphere, there are no purely logical solutions to the conflict, but rather options in a scenario of multiple equilibria. In deregulated markets, this conflict favours the supremacy of unproductive rent (especially those of "inefficiency"), to the detriment of operating profits, affecting investment and productivity growth. Moreover, dysfunctional institutions have the "ability to persist", thus transforming the domination into a "stationary process": the unbalancing impacts of shocks have only limited lifespans. When, in democracy, the Latin American oligarchy limits change and weakens the State through Buchanian-style constitutional straitjackets, they redesign their distributional strategies and absorb elements of opposing ideologies to keep their own hegemonic.
\end{abstract}

\section{Keywords}

Income distribution, inequality, Palma ratio, ideology, "reverse catching-up", institutional persistence, neoliberalism, new left, poverty, Western Europe, emerging Asia, Latin America, Chile

\section{JEL classification}

D31, E12, N36, P16

\section{Author}

José Gabriel Palma holds a PhD in Economics from the University of Oxford, and another in Political Sciences from the University of Sussex. He has taught econometrics, macroeconomics, development and economic history at the Faculty of Economics of the University of Cambridge since 1981. He is also Professor of Economics (part-time) at the University of Santiago. His research focuses on Latin America, Asia, South Africa, Europe and the United States since the neoliberal reforms; income distribution; de-industrialization; financial crises; and the economic history of Latin America. Email: jgp5@cam.ac.uk. 


\section{Introduction ${ }^{1}$}

This article studies the complex and intriguing issue of why the rich tend to stay rich, no matter what the rest of society wishes. To do so, it returns to the Ricardian tradition of understanding the distribution of income as the outcome of the articulation of conflict between rentiers, capitalists and labour (and now bureaucracy as well), where history, politics and institutions matter as much as economic "fundamentals". In other words, the article views income distribution as the articulation of a conflict with a multiplicity of actors and struggles. This conception of inequality is opposed to the neoclassical vision, with its rather mechanical interaction of pure fundamentals, and to that traditional left-wing vision of a single conflict (the class struggle) and only two parties (capital and labour), whereby the conflict takes place within a theological framework.

From our Ricardian perspective, the distributional conflict is naturally "antagonistic", meaning that it essentially belongs to the political sphere, with no purely logical solutions (Laclau and Mouffe, 2011). It is a story of real alternatives in a scenario of multiple equilibria (Palma, 2019a). Furthermore, since in this Ricardian tradition the analytical cornerstone is the distinction between "rent" and "operating profits", in an economy without a strong and intelligent State (in the sense of Mazzucato (2018)) and with deregulated markets, this conflict appears to favour the supremacy of easily obtained, unproductive rent (including those of "inefficiency", which is to say those that hinder growth because they originate from market manipulation) to the detriment of operating profits, hampering investment and productivity growth. This is even more marked in economies with an abundance of natural resources and private appropriation of the rent, since the rent is obtained entirely at the initial extraction phase, meaning that deregulated markets (such as Chile's) only encourage extraction and not diversification of production. This is the key lesson from the "Nordic model": industrialization based on such resources requires a State that coordinates investments in this direction. Otherwise, the rent-seeking class have everything to win in the distributional conflict, and dysfunctional institutions have the "ability to persist". This is particularly significant in analysis of Latin America since the neoliberal reforms and the slowdown in productivity gains -indeed the average for the region has been almost flat since 1980 (The Conference Board, 2020). This transfer of income within the capitalist elite to rentiers, away from entrepreneurs, appears to affect investment, absorption of technology and innovation. ${ }^{2}$

For Ricardo, the need to distinguish between the nature of rent and that of operating profits was fundamental to analysis of distribution and of growth. In fact, according to Ricardo (1817), "Adam Smith, and other able writers not having viewed correctly the principles of rent" had "overlooked many important truths, which can only be discovered after the subject of rent its thoroughly understood". This also relates to the persistence of dysfunctional institutions in Latin America's recent past, and particularly the "iron law of oligarchies", whereby institutions that impede development tend to rebuild (with Chile as a case study).

In the United States, for example, as Acemoglu and Robinson (2006) describe, the traditional landed elites were able to sustain their political control of the South for another century after losing the Civil War by successfully blocking economic reforms that might have undermined their power, and by using their local political supremacy to disenfranchise African Americans and re-exert control over the labour force. In Latin America, likewise, dysfunctional oligarchies have been remarkably effective

\footnotetext{
1 I am grateful to Alex Cobham and Andy Sumner for their valuable contributions to my work on inequality. I am also thankful to many friends and colleagues, in particular to Javier Núñez and the old gang of Cambridge PhD students for valuable contributions to my work on this subject. Contributions were also made, among others, by Mariana Chudnovsky, Camila Cociña, Jorge Fiori, Juliano Fiori, Daniel Hahn, José Antonio Ocampo, Cristóbal Palma, Carlota Pérez, Ignês Sodré, Lance Taylor, José Valenzuela and Robert Wade. Carlos Díaz Alejandro was a great mentor. This paper is dedicated to Diego Armando Maradona, "El Pelusa", a symbol of our Latin American culture in all its glories and flaws -in its vitality and its self-destructiveness (the subject matter of this paper is no exception). The usual caveats apply.

2 See Palma (2019b).
} 
at rebuilding after successive political shocks. No matter what the rest of society has thrown at them, they have been able to reengineer something resembling a Southern-style political settlement, in the sense used by Khan (2018) and distributional outcome.

The case study for this analysis will be how the Chilean elite has been successful in transforming its "Southern-style" preferred scenario into something resembling a "stationary process", in which the unbalancing impacts of shocks (such as, for example, the economic collapse of 1982, and the return to democracy in 1990) have had only limited life spans. Although Latin America's history is rife with shocks, its oligarchies have been able to landscape the new scenarios in such a way that they have been able to continue achieving their fairly immutable rent-seeking goals.

In the case of Latin America, they have done so mainly through three channels: one is by forcing Buchanian-style straitjackets on new scenarios so as to restrict the scope of social change, like when they imposed a draconian constitution and a series of leyes de amarre, or "handcuff laws", on Chile's young democracy. Another is by having the flexibility to reengineer their distributional strategies so as to suit the new scenarios (the main subject matter of this article), while maintaining their collective action. And lastly, they have cleverly absorbed elements of opposing ideologies (such as the need to have effective social protection), so as to keep their ideology hegemonic in the new scenario, as any ideology aspiring to retain hegemony must do, according to Gramsci (1992). Their trump cards are their ruthlessness in the first channel, "fancy footwork", or jogo de cintura e jeitinho, and ability to maintain collective action in the second, and ideological flexibility in "emergency" situations in the third.

From the perspective of flexibility in distributional strategies ("fancy footwork"), as the Chilean experience demonstrates, the Latin American capitalist elite has (so far) been able to successfully follow a complex distributional strategy which could be associated with what in game theory is known as a "Parrondo's paradox", or a winning sequence of strategies that are losing in isolation. ${ }^{3}$ In its traditional formulation, this paradox consists of two games that are played alternately. An analysis of each game in isolation shows both to be losing games if played indefinitely (i.e. they have a negative expectation). However, when they are played alternately, the resulting compound game is, paradoxically, a winning game. In other words, it is possible - as in Chile - to construct a winning strategy by playing apparently losing distributional games alternately.

It remains to be seen whether in the near future the Chilean oligarchy will succeed in doing this again in the new scenario created by the social unrest of October 2019 and the COVID-19 pandemic. That is, whether this time they can successfully reengineer their distributional strategy (for the fourth time since ending the Popular Unity government in 1973): this time, by trying to rebuild their Southern-style rule with their newfound European "new" social democratic-style discourse.

Each of these distributional strategies, no matter how successful, had limited life-spans after which they became counterproductive; if they had continued to be implemented, they would have becoming losing strategies. The secret to the oligarchy's long-term distributive success has been its ability to switch distributional strategy in time (maintaining internal cohesion), while conserving its hegemonic ideology.

If it succeeds once more, this will show how stationary this Southern-style rule is, in terms of its capacity to absorb changes and shocks without altering its fundamental structure, i.e. by making their impact temporary. If it does not, it would mean that the October 2019 social uprising would go down in the annals of Chilean history as the event that finally achieved a permanent effect on the concentrating and exclusionary structure of the Chilean oligarchical rule. That is, it would be the shock that could reshape the Chilean political settlement and distributional structure into something resembling a unit-root-style process: one in which the impact of shocks does not decay over time. Thus, the oligarchy would lose its considerable historical ability to revert change in its favour.

\footnotetext{
3 See Parrondo (1996).
} 
As my analysis of inequality stems from the Ricardian tradition of understanding inequality as the outcome of political articulation of distributional conflict - in which it is history, politics and institutions that really matter - my analysis places the emphasis on Gramsci rather than Kuznets, on Hirschman rather than Solow, and on Mazzucato, Amsden or Pérez rather than on traditional understandings of the relationship between technology and inequality. The emphasis is on the specificities of endogenous processes rather than fundamental forces of the universe.

What matters most in this regard are issues such as what contributes to the formation of collective beliefs. How do consensus types of hegemony emerge? How can they be changed? Why are "antagonistic" conflicts related to the formation of firm political identities, into which so much libidinal energy is invested? In other words, my understanding of inequality is more about ideology than technology; agency than structure (provided that these agencies are able to understand structure); discursive articulation than economic determinism; choice than historical accidents (that Piketty describes ${ }^{4}$ ). In short, it is more about fighting artificially created "distributive failures" in the sphere of production (with Keynesian determination) than surrendering to market inequality in the style of the "new" Left in Europe and Latin America. As analysed in annex A2 (and in detail in Palma, 2019a), although in Europe governments at least make titanic redistributive efforts via taxes and transfers and public debt, they seem to have few qualms about letting major agents distort markets in their own favour, artificially creating a need for mammoth spending on social protection (equivalent to approximately a quarter of GDP if all components are included).

All these complexities make the analysis of inequality particularly difficult, as this phenomenon is intricate and surely overdetermined -making our modest understanding of its dynamics in the real world (despite recent progress) one of the most important analytical failings of current economic analysis. ${ }^{5}$

In fact, Krugman (2011) identified increasing inequality in developed countries and Latin America's perennial economic underperformance as the two greatest analytical challenges today in economics. However, from my perspective, the real analytical challenge is understanding the interaction between the two phenomena in both mature and emerging economies, given that high-income economies of the Organization for Economic Cooperation and Development (OECD) are now determined to mimic Latin America's relentless inequality and perennial underperformance. As previously mentioned, the analysis of Ricardo contributes to this task.

This process of "Latinamericanization" of OECD countries, which I analysed in Palma (2011 and 2016b) and later in Palma (2019a), resembles a reverse catching-up by high-income countries with those in the Tropics. The nature of economic activities may have changed since Ricardo's analysis, but the sluggish economic performance (particularly in productivity) has not, driven by rising inequality with unproductive rent at the forefront (including those of inefficiency) as opposed to operating profit, which has not risen. Nor must it be forgotten that in Ricardo's growth model, a steady state is one in which salaries are stagnant, capitalists do not obtain operating profits and rentiers take the lion's share. The technological paradigm, the financial markets and institutions may have all changed, but the steady state seen in Latin America and the OECD built around this trinity is equally toxic, in terms of inequality, growth and democracy.

The specificity of Latin America's political settlements and distributional structures is not just about artificially self-constructed inequalities that stifle growth, but also how the region's capitalist elites (leaving the issue of whether they really are capitalists for later) have shown a remarkable "ability to persist" during all different forms of crisis, and even those that were directly related to their rent-seeking and inefficient accumulation methods.

\footnotetext{
4 In Piketty's original and highly influential work, there is no room for a natural tendency for inequality to decline even when a country reaches economic maturity. In his (by necessity mechanistic) neoclassical model, increasing inequality is supposed to be intrinsic to a capitalist economy irrespective of its political settlement and level of development (Piketty, 2014). For him, it took accidents such as two world wars and a massive depression to disrupt this supposed pattern (see Palma (2019a, appendix 2) for a discussion of this theme). However, in his next contribution (Piketty, 2020) he finally downplays the role of exogenous factors such as accidents, emphasising that of ideology.

5 For some recent contributions, see Atkinson (2015); Bourguignon (2015); Galbraith (2016); Milanovic (2016 and 2019); Ocampo (2019); Palma (2011, 2016a and 2019a); Piketty (2014 and 2020); Scheidel (2017); and Taylor (2020).
} 
So far, the pandemic has produced yet another example of this phenomenon: while economic activity and the living standards of many are decimated, most large fortunes (particularly financial ones) have continued to expand as in the best of times (Palma, 2020a).

Furthermore, with the pandemic this asymmetry between the oligarchy's capacity to always remain afloat regardless, no matter the cost, and the vulnerability of the rest of society has now undone much of what had been achieved in recent years in Latin America in terms of poverty reduction and minor improvements in inequality.

Latin America's fundamental political economy problem is that there are not many ways to reshape the structure of a system with so little entropy. It is hard to redesign the structure of our society and economy so that it can move forward in time, if the fundamentals of its status quo must remain unchanged, whereby those at the top can continue to appropriate such a huge share of national income doing the type of activities they favour. The main problem with such a system is that so much energy tends to be expended in trying to "stop" time that there is little left to move forward.

One key analytical hypothesis put forward here is that the experience of Latin America shows that rather than thinking in (neoclassical) terms on the possible concrete effects that well-known factors (such as technology or education) may have on inequality, it would be more illuminating to try to understand the concrete expressions that these factors have on inequality. Some of the pieces of the distributional puzzle may be the same in different experiences of inequality, but the way they fit together may differ - sometimes significantly.

That is, the specificity of Latin America's inequality stems from the particular ways in which its distributional struggles have manifested themselves, the different strategies that oligarchies have adopted to face and temporarily overcome these struggles (the main subject herein) and the further distributional challenges created by this process.

Some continue to blame Latin America's inequality on colonial institutions of half a millennium ago, such as mita (mandatory public service by the indigenous population) and the encomienda system (that rewarded conquerors with the labour of particular groups of conquered people). ${ }^{6}$ Others, as in many neoclassical narratives analyse it in a way that somehow resembles Newtonian physics i.e. methodologies of mechanical determinism and simple causalities (in the style of nineteenth century physics, but with a dollar sign).$-{ }^{7}$ Others go as far as blaming the lack of major wars, as supposedly in OECD countries and in some of the emerging Asian economies of the first wave of industrialization it was possible to improve income distribution only in the aftermath of major conflicts (Scheidel, 2017; Piketty, 2014).

The monotonous insistence of many on blaming Latin America's huge inequality on exogenous or crude path-dependency factors is akin to using a pair of scissors to cut an analytical knot they are unable to untie.

In turn, it is unfortunate that Piketty (2014), in his first and most influential book, by unnecessarily relying on the neoclassical theory of growth (factor shares), led the debate over increased inequality in most OECD countries since Reagan and Thatcher, in the wrong analytical direction. Basically, in his neoclassical theory, too much of a good thing -in fact, in his analysis two good things: a great deal

\footnotetext{
6 For Williamson (2009) - quite rightly - the supposed monotonous persistence of Latin America's inequality is just a myth.

7 It should be no surprise that most neoclassical analyses of Latin America's inequality fail to explain why it is much higher than in many middle-income countries elsewhere, for example, in Asia, North Africa, the former Soviet Union and Eastern Europe (among others), even though some of the issues they highlight apparently point in the opposite direction. For example, almost all of these countries tend to have even more market failures and rigidities than Latin America; they have relative price structures, institutions and social capital that are even less 'right'; they have property rights over physical and intellectual assets that are less well-defined and less well-enforced; they have educational systems that are even more segmented, with the poor often getting an even more dismal deal; they discriminate on gender and race even more than in Latin America; they have even greater shortages of skilled labour; their democracies are even more 'low intensity', and with more problems of 'governance'; they have an even greater dependence on political connections, cronyism and corruption to achieve success in business. But, despite all of this, these countries are less unequal than Latin America (sometimes significantly so).
} 
of investment and high elasticity of factor substitution (production flexibilities) - unfortunately ends up producing higher inequality. It is hard to imagine a construct that would idealize inequality more than this! ${ }^{8}$

Instead, as Stiglitz (2012) and I have argued (Palma 2011, 2016a and 2019a), inequality is a choice between perfectly feasible alternatives in a world of multiple equilibria. As Sartre (2004) argued, nothing reveals more transparently who we truly are than the choices we choose to make; this is certainly true for inequality. The bottom line, as the title of Palma (2016a) indicates, is that every country deserves the inequality it has.

It is just not credible to continue claiming that we are innocent bystanders of supposedly "exogenous" factors. ${ }^{9}$ That is, one must always reject mechanical determinisms and simple causalities and insist on our ultimate freedom and responsibility. "I am my freedom", says a character in one of Sartre's plays (Sartre, 1946). Every act is a self-defining one, and no act of this kind can really be blamed on so-called exogenous factors. The all-time classic quotation on this matter is provided by Shakespeare, in a speech in King Lear:

This is the excellent foppery of the world, that, when we are sick in fortune, - often the surfeit of our own behaviour -, we make guilty of our disasters the sun, the moon, and the stars: as if we were villains by necessity; fools by heavenly compulsion; knaves, thieves, and treachers, by spherical predominance; drunkards, liars, and adulterers, by an enforced obedience of planetary influence; and all that we are evil in, by a divine thrusting on: an admirable evasion of whoremaster man, to lay his goatish disposition to the charge of a star! (Shakespeare, $\mathrm{n} / \mathrm{d}$ )

At least it seems that it is finally becoming "common sense" (in Gramsci's perspective) that the increasing market inequality that has characterized the global landscape since Reagan and Thatcher has been a self-constructed distributive failure. Warren Buffett explains this clearly and succinctly: "There's class warfare, all right, but it's my class, the rich class, that's making war, and we're winning" (see Stein, 2006). As for growing inequality, fundamentals? What fundamentals?

Essentially, if Adam Smith's "invisible hand" (Smith, 1776) were to exist, and was what guided allocation of resources, this relentless increase in inequality, particularly in market inequality (see annex A2) could not have taken place, because market compulsions would have put a stop to it. Its foundations are artificially tailor-made. In fact, it feels almost tedious even having to state that increasing market inequality has been an artificially constructed distributive failure, a mere distortion of the market; it is as if somebody at the circus were to point out that when the magician saws a woman in half, "it's only a trick!".

\section{Some background issues}

\section{Ratchet effects, or the "support levels" of increases in inequality}

One of the issues I shall analyse in this article (hitherto rather disregarded in the literature), which has proved to be an important distributional stylized fact in post-war Latin America, is the distributional-ratchet effect resulting from the fact that improvements in inequality have tended to be temporary, while deteriorations

8 For a critique of Piketty's neoclassical analysis, see Rowthorn (2014); Taylor (2014 and 2020); Harcourt (2015); and Palma (2019a, especially appendix 2).

9 Kaldor (1955) was the first to break the neoclassical mechanistic spell on the determinants of inequality in his analysis of the Harrod-Domar model, which elicited a strong reaction from Solow (1956). While Kaldor dealt with the Harrod-Domar instability issue by allowing for endogenous changes in the distribution of income between wages and profits, Solow argued that it was impossible to think of an efficient distribution of income that was not automatically determined by the value of marginal productivities. 
have more permanent effects. That is, the well-known difficulties in reversing social dynamics seem to apply only to increases in inequality. Developments in Chile clearly illustrate this: the leap at the top end of the income structure has been difficult to revert (see figure 1).

Figure 1

Chile: share of market (pre-tax) income of the wealthiest 1\%, the distributional legacy of the dictatorship, 1964-2015

(Percentages)

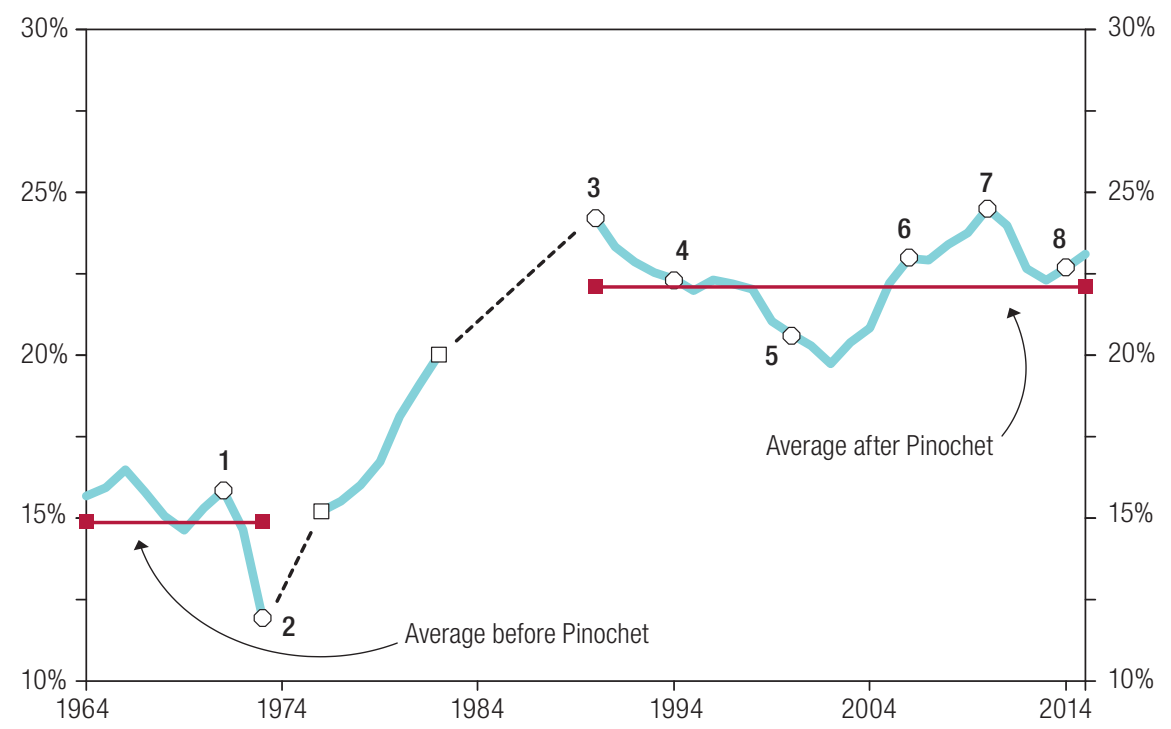

Source:World Inequality Lab, World Inequality Database, 2020 [online] http://wid.world/, on the basis of J. Atria and others, "Top incomes in Chile: a historical perspective of income inequality” (1964-2015)”, Working Paper Series, No. 2018/11, World Inequality Lab, 2018.

Note: Dotted lines refer to years for which no data are available. For 1964-1981 "income" refers to fiscal income and from 1990 onward to pre-tax national income. Averages are harmonic means ${ }^{10}$ (1957-1973 and 1990-2015). Three-year moving averages.

1. Election of Salvador Allende.

2. Pinochet seizes power in a coup d'état.

3. Pinochet is forced to hold a plebiscite on whether he should remain in power for another eight years, which gives rise to the first democratic government (centre-left coalition, the "Concertación") after Pinochet loses the plebiscite. 4, 5 and 6. Next three centre-left governments.

7. Election of a centre-right government.

8. The centre-left returns to government.

What is most striking is that this ratchet at the top occurred despite the fact that Pinochet lost the plebiscite by a wide margin, and that in period following the return to democracy there were four consecutive centre-left governments, all within a political coalition that included President Allende's Socialist Party. Moreover, this political coalition had the support of a clear majority in both presidential and parliamentary elections throughout, and one banner in their discourse and manifestos was to reduce inequality. Sections III to VII attempt to explain why they failed in this aim (at least in terms of being able to reduce the income share of the rich).

Standing out among other regional distributional ratchets is the case of Brazil. The Brazilian oligarchy was not only able to sustain the increase in inequality that followed the 1964 coup d'état, but also continued enjoying these gains long after the return to democracy -in fact, at least until the election of Luiz Inácio Lula da Silva (see figure 2). ${ }^{11}$ This remarkable persistence of high inequality (with at best minor improvements) applies to other countries of the region as well.

\footnotetext{
10 For the non-specialist, the harmonic mean is one of the three Pythagorean means. It is more appropriate for the average of ratios as it mitigates the impact of outliers; it also contains more information than the median. It is the reciprocal of the arithmetic mean of the reciprocals.

${ }^{11}$ See Fishlow (1972) for details on the rapid deterioration of inequality after the 1964 coup.
} 
Figure 2

Brazil, Mexico, Costa Rica and Colombia: market income and disposable income Gini indices, 1960-2018
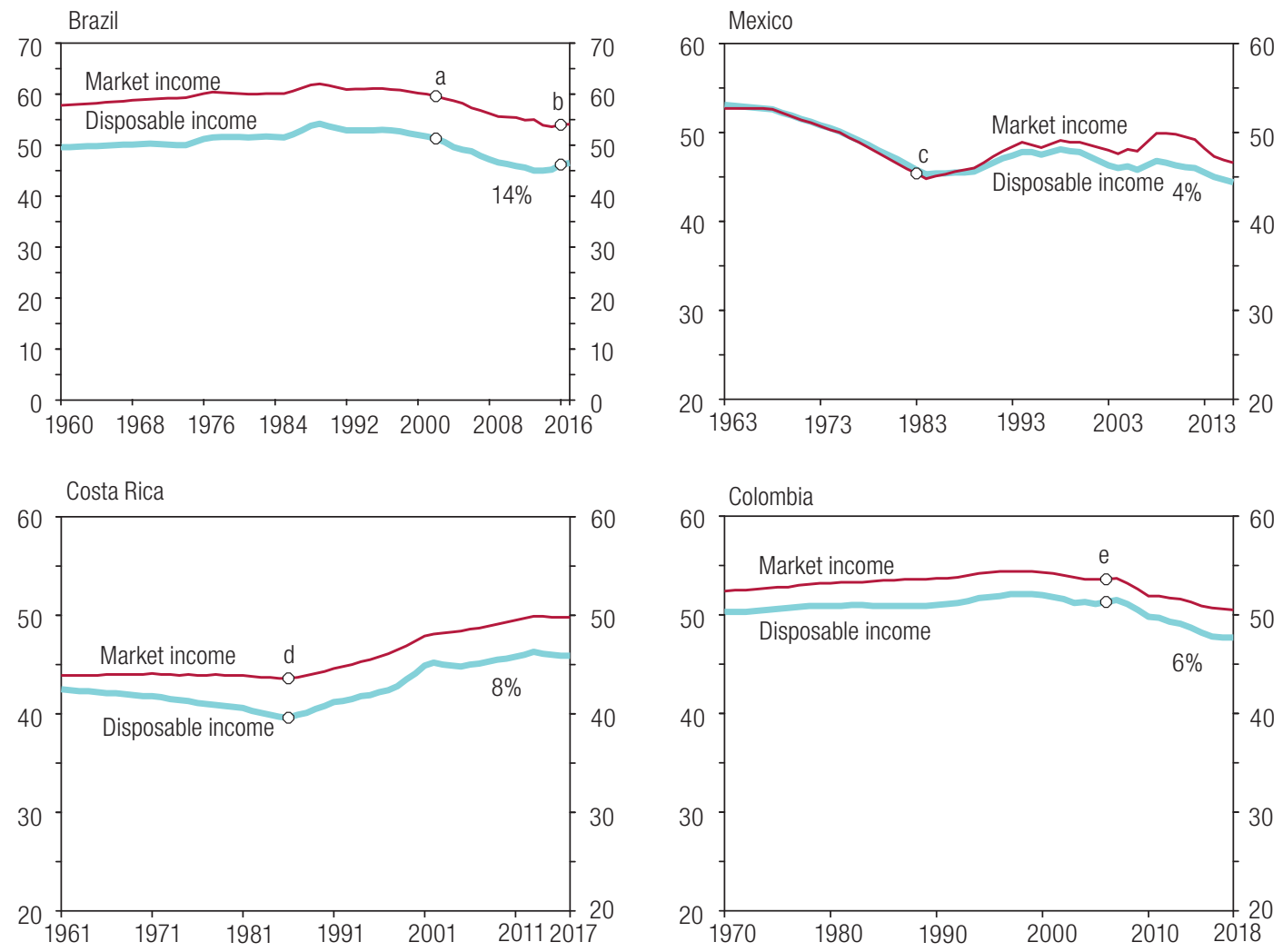

Source: F. Solt, "Measuring income inequality across countries and over time: the Standardized World Income Inequality Database", Social Science Quarterly, vol. 101, No. 3, SWIID version 9.0, October 2020 [online] https://fsolt.org/swiid/.

Note: Percentages shown in the panels indicate the relative reduction of the market income Gini index after taxes and transfers.

a. Election of Luiz Inácio Lula da Silva.

b. Parliamentary coup d'état against Dilma Rousseff.

c. Election of Miguel de la Madrid.

d. Election of Oscar Arias.

e. Re-election of Álvaro Uribe.

As figure 2 indicates, countries of the region hardly get into double figures when it comes to improving their market inequality via taxes and transfers. These efforts are minimal compared to those of European countries, which improve the Gini by up to 50\% (see annex A2). They are even meagre compared to those of the United States under the administration of President Trump (25\%). Why did Latin America achieve so little despite so much "progressive" talk?

Moreover, although Brazil's 14\% reduction in its market Gini is the largest in the region - like South Africa's similar figure - it is a particularly modest effort since in both countries fiscal revenues are relatively similar to the OECD average (Di John, 2006; Lieberman, 2003; OECD, 2020a). The key difference between them is that South Africa, despite its relatively progressive taxation, fails to achieve more due to an ineffective system of transfers to the poor, whereas Brazil, although it has (or should I now say it had?) a more effective programme of transfers, falls down badly on its highly regressive tax structure.

Indeed, another source (World Inequality Lab, 2020) even questions Brazil's relatively small improvement in inequality in disposable income shown in household surveys during the four successive governments of the Workers' Party (PT). It is very likely that the Brazilian ratchet - which favours high-income groups, like its Chilean counterpart - has in fact remained in place, even during the terms of centre-left governments (see figure 3). 
Figure 3

Brazil: share of national pre-tax income of the wealthiest $1 \%$ and wealthiest $10 \%$ and Palma ratio on inequality in disposable income (post-tax and transfers), 2001-2019

(Percentages)

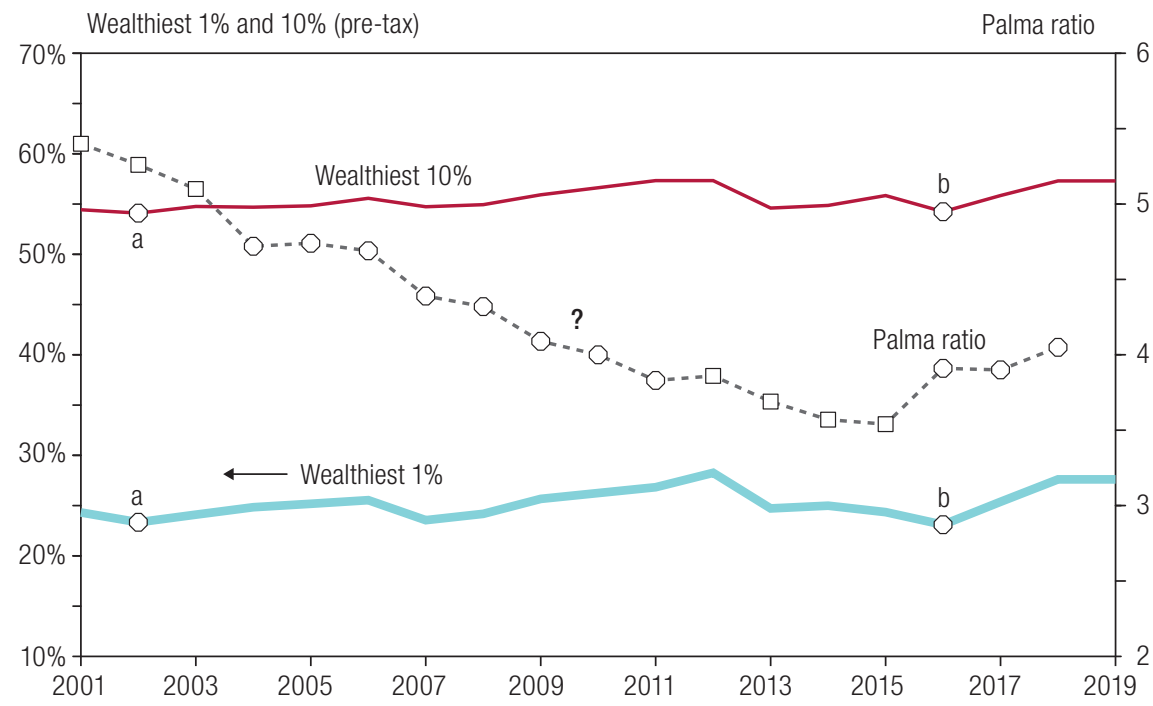

Source:World Inequality Lab, World Inequality Database, 2020 [online] http://wid.world/, on the basis of M. De Rosa, I. Flores and M. Morgan, "Inequality in Latin America revisited: insights from distributional national accounts", Technical Note, No. 2020/02, 2020 (for pre-tax income); and J. G. Palma, "Behind the seven veils of inequality: what if it's all about the struggle within just one half of the population over just one half of the national income?", Development and Change, vol. 50, No. 5, September 2019 (for the Palma ratio).

a Election of President Luiz Inácio Lula da Silva.

b Parliamentary coup d'état against President Dilma Rousseff.

There is little indication that the small decline that supposedly occurred in the income share of those at the top during the PT era, according to household budget surveys, is in fact real, given the new pre-tax evidence and the regressive tax policies of Brazil. In a similar fashion to Chile, as shown figure 9 , the most likely scenario is that this is a result of the growing inability of budget surveys to reflect the income of the rich, in this increasingly financialized world (that is not short of tax havens). Even (successful) PT period policies to increase the income share of the poorest (such as those to reduce poverty, formalize labour contracts and increase the minimum wage) do not appear to be sufficient to support the supposed improvement in the Palma ratio (see the question mark in figure 3).

Furthermore, these policies, and policies to slow the destruction of the Amazon, are now at risk not just because of the economic impact of the pandemic, but also due to current government politics on the COVID-19 pandemic, misguided nationalism on the Amazon, and early Washington Consensus/ Chicago-style neoliberalism in economic policies. ${ }^{12}$

The same scepticism is warranted by Chile's much-heralded minor improvements on inequality (see figures 1 above and 9 below). For those in Latin America wanting to improve inequality, it has proved much easier to "talk the talk" than to "walk the walk"!

\footnotetext{
12 In view of the current pandemic, if we continue to destroy habitats and ruin ecosystems, other viruses are more likely to jump from animals to humans; in particular, the continued destruction of the Amazon could bring about the next health crisis. At the time of writing, even areas outside the Amazon, such as Pantanal, are now being burned to the ground -in fact, more than a quarter of its tropical wetland has already been destroyed. As Einstein is reported to have said, "Two things are infinite: the universe and human stupidity (and I'm not sure about the universe)."
} 


\section{Why dysfunctional institutions are so good at recreating themselves when shocked out of balance}

As suggested above, all this brings us back to the complex issue of persistence in dysfunctional institutions, and in particular how they are so effective at recreating themselves - as the landed elite did in the South of the United States after losing the Civil War. The Chilean oligarchy was able to do the same, despite badly losing the 1988 plebiscite and four presidential and parliamentary elections thereafter. As times have changed, the oligarchy has found it more effective to co-opt its object of hate, than to lynch it. However, times have not changed that much: the oligarchy managed to impose on the majority a straitjacket Constitution, with many institutions above democratic control. In turn, thanks to the supramajorities required in Parliament for anything significant, and the "appointed" Senators (including Pinochet himself), those institutions above democratic control made it practically impossible to change the Constitution. It took a social explosion of the magnitude of that of October 2019 to shock Chile's "Southern-style equilibrium" out of balance enough to force business leaders to convince the powers that be to start constitutional change. When the referendum on this possibility took place exactly a year after the social unrest (and 30 years after the return to democracy), it attracted an 80\% positive response.

Regarding the role played by the "new" Left in all this (see annex A1), according to Gramsci (1992) any ideology aiming to remain hegemonic has to be able to absorb elements of opposing ideologies; but it has to do so in an imaginative way, articulating them with the essence of its own ideology. That is, for a consensus to remain hegemonic, dominant groups have to make ideological concessions to subordinate groups, but without endangering their domination. This was what business and right-wing political parties did so well in Chile after their defeat in the 1988 plebiscite; this helped them control the transition to democracy, whereby the elected centre-left authorities could run the government but the business elite retained de facto political power and the military (with Pinochet as Head of the Armed Forces for another eight years) retained its power through force.

The centre-left parties, instead, inspired by the "Third Way" of the Western European new social democracy, made that Gramscian ideological integrative effort of imagination in a timid, often opportunistic way, and with little creativity. As a result, they allowed the new neoliberal economic ideology to simply replace its previous social-democratic ideology.

Here the similarities with what happened in South Africa after the beginning of democracy in 1994 are also more than superficial: the Afrikaner political elite may have lost the major battle, but the white elite (partly helped by the co-option of a critical mass of the African National Congress (ANC) elite) is still appropriating the highest share of income of any elite in the world (Palma, 2011, appendix 3).

From this perspective, as Acemoglu and Robinson (2006) point out, one should never lose sight of the distinction between the two components of political power: de jure and de facto power. The political misfortune of Latin America is that the de facto political power of the oligarchy is such that, to date, these dysfunctional institutions have been able to survive all political and economic shocks fairly unscathed. The capture of the Latin American "new" left has proved to be just a chapter in that history (see annex A1).

\section{Inequality as an anti-coordination game -as in a game of chicken (or "hawk-dove")}

In game theory, this type of game is a model of conflict associated with a diverse range of social conflicts. It is a question of which player yields first, as in the 1955 film Rebel Without a Cause; stolen cars are raced towards an abyss, and whoever jumps out first will be deemed a "chicken". Bertrand Russell (1959) also famously used it as a metaphor for the game of nuclear brinkmanship, in which the final result could be one nobody wanted. 
This is an "anti-coordination" game because the shared resource is rivalrous (although non-excludable). Namely, sharing comes at a cost, i.e. it is subject to a negative externality. This, of course, need not be the case in distributional games if the players are involved in a Marshallian efficiency wage scenario because of the likely positive feedback between wage growth and productivity growth. However, try explaining that to a short-sighted oligarchy that is convinced its income depends on not understanding.

The unstable state of affairs that characterizes a game of chicken leads to a situation in which there are only two possible (and opposite) Nash equilibria, corresponding to the preferred strategy of each player. ${ }^{13}$ Anything in between is an unstable mixed outcome, always subject to being challenged. One that is the outcome of temporary and precarious arrangements of contingent practices, as in other antagonistic conflicts, is likely a result of practices that seek stability in a contingency. So, one effective tactic (that is particularly relevant here) would be for one party to signal his or her intentions convincingly enough. In other words, the game could easily become one of brinkmanship, designed to avert the possibility of the opponent switching to aggressive behaviour. This is one reason why in an antagonistic distributional conflict an "irrational" player can easily have the upper hand. And since credible threats - no matter how irrational - can be very effective, in terms of inequality the set of institutions and rules within which a distributional struggle is played out becomes crucial, as it can contribute to the credibility of one or another party.

In fact, one way of understanding the neoliberal transformations is in terms of the creation of a specific institutional scenario where the threats of the elite -irrational though they may be- should be taken extremely seriously by workers and the State. By now it seems clear that these reforms had little to do (in both mature and emerging economies) with increased economic efficiency, and a lot to do with helping capital to recover its power and regain the legitimacy lost through the crisis of the 1930s, the determination of President Franklin D. Roosevelt and his New Deal, the horror of war, the increasing organization of the working class, and the genius of Keynes. After the war, even in the United States, the income of the bottom $40 \%$ grew faster than that of the richest $1 \%$ during three consecutive decades (Palma, 2019a).

One of the aims of the 1980s reforms was to reverse this. From the perspective of Walter Benjamin (1968), all class society is in a permanent state of emergency because the ruling class is always under threat. The aim of neoliberalism, then, was to build a consensus and a praxis -and a "common sense" - that would help to create a class society in which the elite is not exposed to this threat, owing to their ability to debilitate the rest of society by imposing on them a continuously insecure life. ${ }^{14}$ In this scenario, a mobile and malleable agent could achieve an unrivalled dominance. In this context, big capital (especially financial capital) rules and any alternative national development and autonomy strategy carries the risk of becoming a collective suicide pact.

This brings to mind Foucault's (2008) proposition that neoliberalism is not really a set of economic policies but a new and very effective technology of power (Frangie, 2008; Palma, 2016b). So, workers are now back to old-fashioned precarious jobs; social security networks are being deliberately made increasingly porous; and easy access to persecutory debt is leading to what Krugman (2005) calls "the return to a debt-peonage society". In turn, "subsidiary States" tightly limit the room for manoeuvre in terms of economic policy or agencies, other than those that are meant to keep capital sweet.

The uncertainties of a new technological paradigm do not help either, as although they give opportunities to financial capital and a few particular skills and innovations, they also bring further uncertainties to the majority of workers and the State (Pérez, 2002).

\footnotetext{
${ }^{13}$ In this game, the strategic space for both players would be "demand redistribution" and "do not demand redistribution" for the majority player, and "yield to redistribution" and "do not yield to redistribution" for the capitalist elite. This is a multiple equilibria story. In turn, the Nash equilibria would be "demand redistribution", "yield to redistribution", and "do not demand redistribution", "do not yield to redistribution" for the majority player and elite player, respectively. In the first, the majority player has the upper hand, while in the second it the elite does.

${ }^{14}$ See Arantes (2007).
} 
The bottom line for neoliberalism is how to reconstruct a scenario in which capital is known to have the power to pull the plug whenever it sees something it does not like. Under these circumstances, the ideological acceptance of the "preferred" (game) strategy of the elite could be considered smart, rather than chicken, making such an unfavourable position more bearable. Shared pain can even feel reassuring. After all, as Benjamin (1968) also reminds us, before all philosophy comes the struggle for subsistence.

In developing countries, the challenge for capital to develop more effective forms of legitimacy, and more sophisticated technologies of dispossession of value generated by others, has been even greater. In the new complexities of a post-Cold-War scenario, the existence of a dictator or two, such as in Chile's military regime, is no longer enough.

The neoliberal discourse may have erupted onto the world stage during the thirst for new ideas in the 1970s, promising order, market efficiency, individual initiative, non-paternalism, sound macroeconomics and a new concept of the State, but what it ultimately offered to workers and the State was a life permanently on the edge and a high-risk and unstable order in which only capital, with its mobility and malleability, could really thrive, with the State mostly reduced to putting out fires, in a situation full of emergencies.

In a way, Keynes' ideas were precisely about fighting these types of inefficient and old-fashioned "anti-coordination games", searching for more efficient and stable cooperative outcomes. The mass production for mass consumption technological paradigm also helped this type of scenario, especially as it was in its "mature stage" (Mazzucato, 2013 and 2018; Pérez, 2002). However, if capital or labour pushed things towards brinkmanship scenarios, what was imperative for Keynes was to prevent a player prone to irrational behaviour — such as financial capital - from intimidating the other players in a game of chicken.

\section{The ability to persist of the Chilean capitalist elite}

As already suggested, one possible explanation of Chile's stubbornly stable marked inequality is that it has benefited from Parrondo's paradox in the sense that the Chilean oligarchy seems to have successfully followed a complex distributional strategy which could be associated with that logic. In game theory, the secret to that paradox to switch strategy when the game could become counterproductive (when it has passed its "sell-by" date).

There are many examples of these somewhat counter-intuitive scenarios; in financial markets, for example, there are strategies whereby a player could be guaranteed to lose all his money if they are played permanently, but which could generate a winning streak if played alternately. ${ }^{15}$

In the case of Chile, this scenario is rather transparent, although the oligarchy's winning strategy has involved more than two games, so its mathematical solution would imply a more complex convex scenario than the usual linear combination of two games. ${ }^{16}$

The basic dilemma for any oligarchy determined to maintain such degrees of inequality is how to construct a winning strategy that is sustainable when in a democracy, given the fact that it is such a tiny minority, and that the distributional outcome that it seeks is so remarkably unequal.

What is needed to build a long-term winning strategy of this type is both the flexibility to switch between strategies as soon as they become counterproductive, the ability to maintain one's hegemonic ideology, and the capacity to solve any internal "collective action" problem that may emerge along the way in order to ensure internal cohesion - so that members act together, even when individuals may

\footnotetext{
${ }^{15}$ See, for example, Blakeslee (2000).

${ }^{16}$ See Key, Klosek and Abbott (2006) for an example of a three-periodic game.
} 
have incentives to free-ride. This phenomenon is sometimes linked to the concept of "elite closure". According to Adam Smith (1776, volu. I, ch. 5), the elite's greater capacity for "collective action" helps it enormously to take the lead in the distributional conflict.

These are crucial components for the oligarchy's ability to persist. From this perspective, North and others (2007) were right when they developed the "limited access order" hypothesis: how elites able to maintain cohesion can divide up the control of rents and block the access of others.

\section{Strategy 1. How to convert the probabilistic outcome of a distributional game into a deterministic winner-takes-all scenario using terror}

When Chile elected a left-wing government in 1970 - and that government (unusually enough) was prepared to implement the programme for which it had been democratically elected, including redistributive policies (see figure 1 above, and figures 5 and 6) - the Chilean oligarchy panicked, because those policies were going to tip the scales of the distributional game to the workers' advantage, and chose the nuclear option of a coup d'état (in a country with a long democratic tradition).

In other words, the oligarchy chose to transform the distributional scenario from one in which the poor were getting the upper hand, to one in which it could implement its own "preferred" distributional strategy unimpeded -i.e. a winner-takes-all scenario. In this new Nash equilibrium, with its particularly asymmetric set of distributional strategies, and the corresponding payoffs, one player could convince the majority of the futility of challenging the situation while it had at its disposal the whole apparatus of State terror.

The outcome of this new "insatiable appetite" strategy -the oligarchy's "strategy 1 " in this narrative - is evident in figure 4.

Figure 4

Chile: changes in share of income by income decile, 1973-1987

(Percentages)

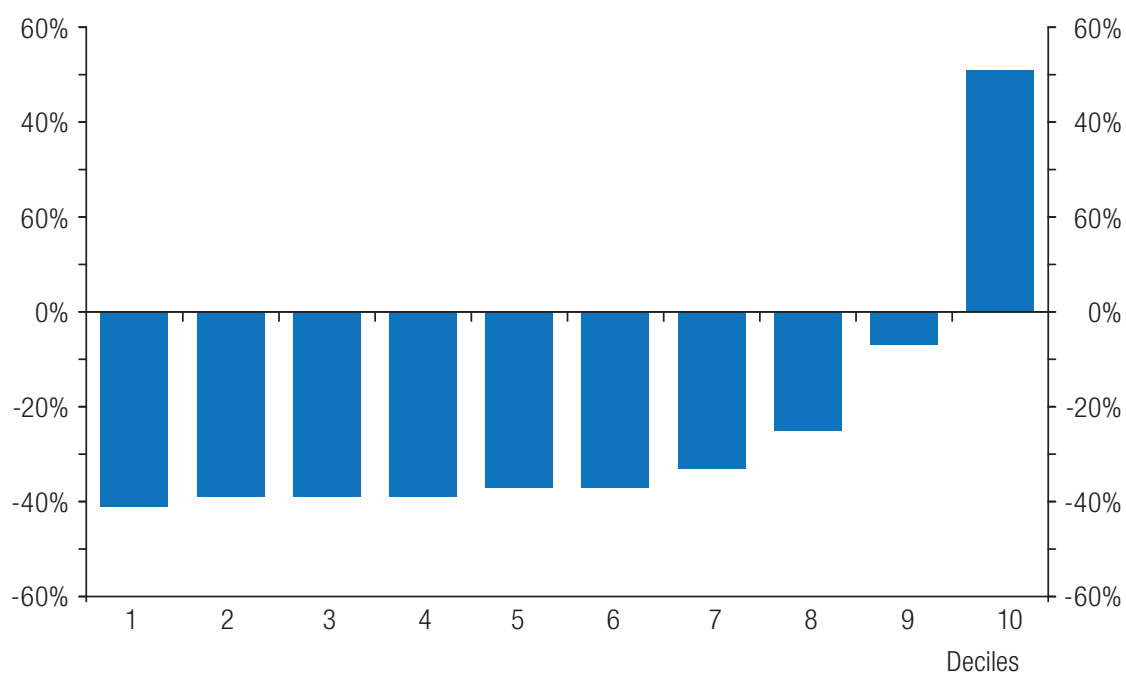

Source: Prepared by P. Jervis and the author, on the basis of Centro de Microdatos (CMD), "Encuesta de Ocupación y Desocupación en el Gran Santiago 2019", Faculty of Economics and Business, University of Chile, 2020 [online] http://documentos. microdatos.cl/Encuestas/Ocupacion/OcupacionDesocupacion?C=T1.

Note: Data refer to per capita household income in Greater Santiago (where about 40\% of the population lives). It excludes from family incomes those of lodgers and domestic workers living in the house, those declared as "zero", "does not know", and "'no response". 
In fact, in this survey the share of the tenth decile increased from $34 \%$ of national income to no less than 52\% between 1973 and 1987 (the year of the plebiscite), taking even from the share of the ninth decile. This scenario resembles a postmodern Robin Hood who not only robs the poor to give to the rich, but also robs the rich to give to the even richer!

\section{Strategy 2. The return to democracy creates a new challenge for the elite: how to reconstruct its legitimacy via a more refined technology of power}

No matter how much terror could be generated by the State's repressive apparatus in the dictatorship, the oligarchy could not play "strategy 1 " indefinitely. Inevitably, towards the end of the 1980s, the distributional game began to move away from its determinist scenario, slowly returning to its normal probabilistic situation (with a more mixed and unstable distributional outcome) because of growing popular unrest. That is, the oligarchy's strategy 1 started to become counterproductive (i.e. a losing strategy) as the majority (especially new generations) began to lose their fear of challenging the oligarchy's preferred strategy. The emperor had no clothes (only a repressive apparatus).

As a way out of this conundrum, General Pinochet's government sought to legitimize its rule by calling a plebiscite in 1988, which was to allow him to remain as Head of State for another eight years. The government lost the vote, and by a wide margin, despite having tried to reverse some of the worse aspects of its distributional policy at the last minute (see movement from 3 to 4 in figure 7). ${ }^{17}$

In fact, in trying to improve his democratic credentials, Pinochet shot himself in the foot: just before the plebiscite, he signed the Convention against Torture and Other Cruel, Inhuman or Degrading Treatment of Punishment. Ironically, the ratification of this Convention was what allowed Judge Garzón from Spain to ask the Government of the United Kingdom for Pinochet's extradition in 1998. This was the first time that a former head of government was arrested under the principle of universal jurisdiction. Also, and again for the first time, this enshrined in international law the principle that the immunity (current or former) Heads of State does not apply to crimes against humanity.

As Pinochet lost the plebiscite and his supporters lost the subsequent presidential and parliamentary elections by a wide margin, the elite had little choice but to switch to a more sophisticated distributional strategy. This they did rather effectively.

The key characteristic of strategy 2 is that it resembled the old Roman Catholic practice of indulgences, whereby sinners (in this case the sacrilegious oligarchy) could buy certificates that stated that through penitence their sins had been absolved.

The vital point for the oligarchy was recovering their democratic legitimacy; to achieve this, what could be better than supporting some distributional policies of the new centre-left government and a tax reform? However (with the help of the life senators appointed by Pinochet), they succeeded in imposing the condition that this would be a temporary measure. They also supported an increase in the minimum wage and other policies for poverty reduction, a mild reform of the labour legislation, and so on.

A crucial component of strategy 2 was the need for the oligarchy to rebuild its traditional distributional alliance with the middle and upper-middle strata since, as figures 4 and 5 indicate, they too had been squeezed during the winner-takes-all distributional strategy. Therefore, the oligarchy also supported (and pressured) the centre-left government towards different measures to benefit this

17 In the other household survey (CASEN), this movement from point 3 to point 4 is less sharp. 
sector. As a result, the share of income deciles 5 to 9 recovered some of the ground lost during the dictatorship, but it then stabilized at a level below $50 \%$ of the national income -a level that was well below what it had achieved during the presidency of Salvador Allende, reflecting how difficult it is to recover lost ground in a distributional game (see the ratchet effect in figure 5).

Figure 5

Chile: percentage of income of the middle and upper-middle strata (deciles 5-9), 1957-2014 (Percentages)

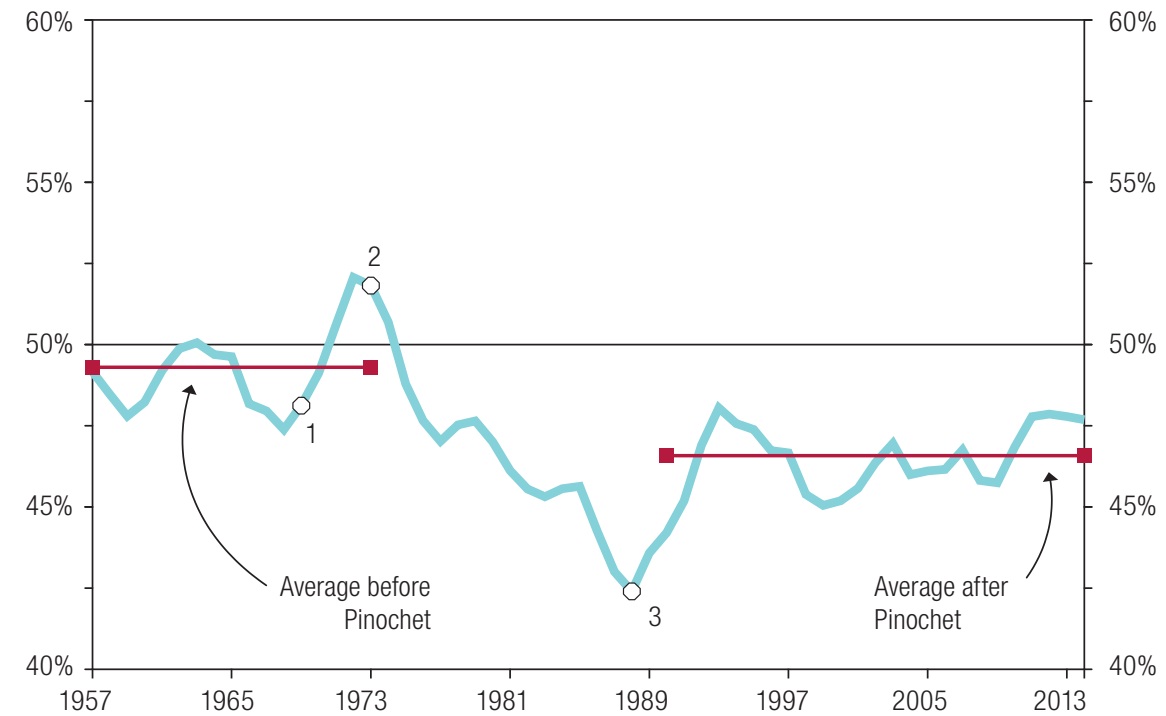

Source: Prepared by P. Jervis and the author, on the basis of Centro de Microdatos (CMD), "Encuesta de Ocupación y Desocupación en el Gran Santiago 2019", Faculty of Economics and Business, University of Chile, 2020 [online] http://documentos. microdatos.cl/Encuestas/Ocupacion/OcupacionDesocupacion?C=T1.

Notes: Averages are harmonic means (1957-1973, and 1990-2014). Three-year moving averages.

1. Election of Salvador Allende.

2. Pinochet seizes power in a coup d'état.

3. Election in 1989 of the first of four consecutive centre-left governments after Pinochet lost the 1988 plebiscite, followed by a right-wing government in 2010. In the CASEN survey, the cycles after point 3 are less pronounced.

The key message of this figure is that Chile is one of the very few countries in the world where deciles 5 to 9 are unable to defend their half of national income (Palma, 2019a). In addition, this image does not fit into a scenario where public choice theory applies, whereby agents make decisions according to their outcomes and those decisions are rational, favouring logic, objectivity and analysis over subjectivity and intuition. In Chile, in contrast, figure 5 shows that the middle strata (deciles 5 to 9) make decisions without considering outcomes (for example, majority opposition to Allende, mass support for Pinochet). Perhaps identity, subjectivity and intuition (we shall call this ideology for short) play a more important role in decision-making than Buchanan's primitive economism (he should have studied in Chicago!).

Figure 6 shows the changes in the income share of the poorest $40 \%$.

As with the middle and upper-middle strata, the share of the bottom $40 \%$ did recover after the return to democracy. However, and as opposed to the downward ratchet of deciles 5 to 9 shown in figure 5, during the period covered by the oligarchy's strategy 2 this share did return to pre-1973 levels -thanks to distributional policies of the centre-left governments, which targeted the bottom of the income scale. In fact, when the centre-left lost on its fourth attempt at re-election in 2010 this income was trending upward. 


\section{Figure 6}

Chile: percentage of national income of the poorest 40\%, 1957-2014 (Percentages)

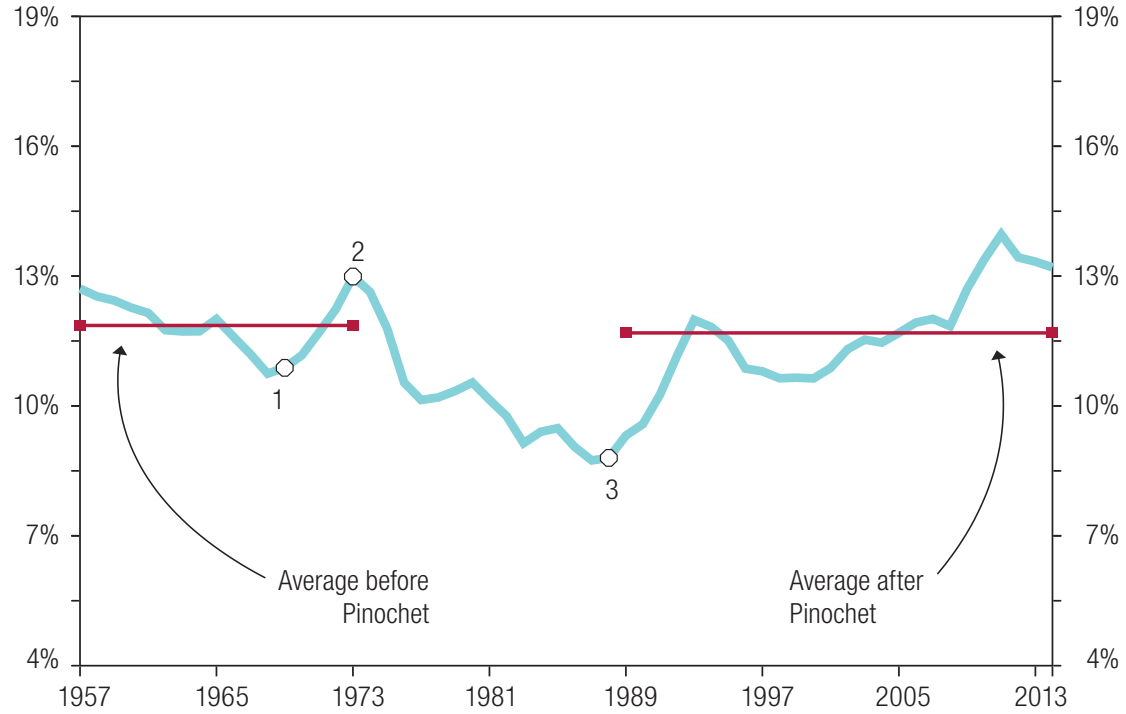

Source: Prepared by P. Jervis and the author, on the basis of Centro de Microdatos (CMD), "Encuesta de Ocupación y Desocupación en el Gran Santiago 2019”, Faculty of Economics and Business, University of Chile, 2020 [online] http://documentos. microdatos.cl/Encuestas/Ocupacion/OcupacionDesocupacion?C=T1.

Note: Averages are harmonic means (1957-1973, and 1990-2014). Three-year moving averages.

1. Election of Salvador Allende.

2. Pinochet seizes power in a coup d'état.

3. Election in 1989 of the first of four consecutive centre-left governments after Pinochet lost the 1988 plebiscite, followed by a right-wing government in 2010 .

All in all, strategy 2 was a great success for the elite. Although it may well have lost some of its share in income, these elements of strategy 2 were like a sacrifice in a game of chess, where deliberately losing a piece could help win the game.

However, as the oligarchy clearly had no intentions of maintaining the pretence of its new progressive face indefinitely, as soon as it had succeeded in recovering a minimum of democratic legitimacy, it was able to move credibly to a new, more aggressive distribution strategy - strategy 3.

Therefore, despite the fact that it was a political minority (but greatly helped by the ability to leverage the tailor-made legal scenario built by Pinochet's Constitution and his "handcuff laws"), it began adopting a more aggressive strategy with actions such as defeating in Parliament (with the help of its appointed senators) a new labour reform, and reversing the tax reforms of the first democratic government. ${ }^{18}$

It is remarkable how the oligarchy, with the support of its military allies, managed to re-establish the legitimacy and hegemony of its ideology - but now in democracy. The key question is, how was that possible? How could they succeed in creating a hegemonic consensus around their discourse of deregulated market supremacy and trickle-down economics? And why was the "new" left not just ideologically neutralized, but also seduced into cheerleading this transformation? (If you can't beat them, join them, perhaps?).

\footnotetext{
18 This is in a country where, even with these reforms, the tax take was about 20\% of GDP (OECD, 2020b), and where the higher the income decile, the lower the proportion of income paid in taxes (see Engel, Galetovic and Raddatz, 1999; and López and Miller, 2008). Also, as in the rest of Latin America, income tax evasion was rampant -ECLAC (2016) calculated that tax evasion represented almost $7 \%$ of the regional GDP.
} 


\section{Strategy 3: how could something resembling a Nash equilibrium, built around the elite's preferred distribution strategy, with its extreme inequality and unilateral payoffs, emerge in a democracy?}

The first key aim of strategy 3 was to stabilize the distributional outcome of strategy 2; its motto was "no more concessions!". The second was to entrench the oligarchy's ideology as unrefutably hegemonic. When both objectives were achieved, which coincided with the early stages of the second presidency of the centre-left, the oligarchy could finally drop the façade and once more distort inequality in its favour (now in a democracy). Figure 7 summarizes the outcome of the oligarchy's three strategies: 1, higher inequality through terror, 2, the process of re-legitimizing capital, and 3, sustaining higher inequality through more refined technologies of power, based on more sophisticated forms of domination. ${ }^{19}$

Figure 7

Chile: distributive impact of strategies 1, 2 and 3 (Palma ratio), 1957-2010

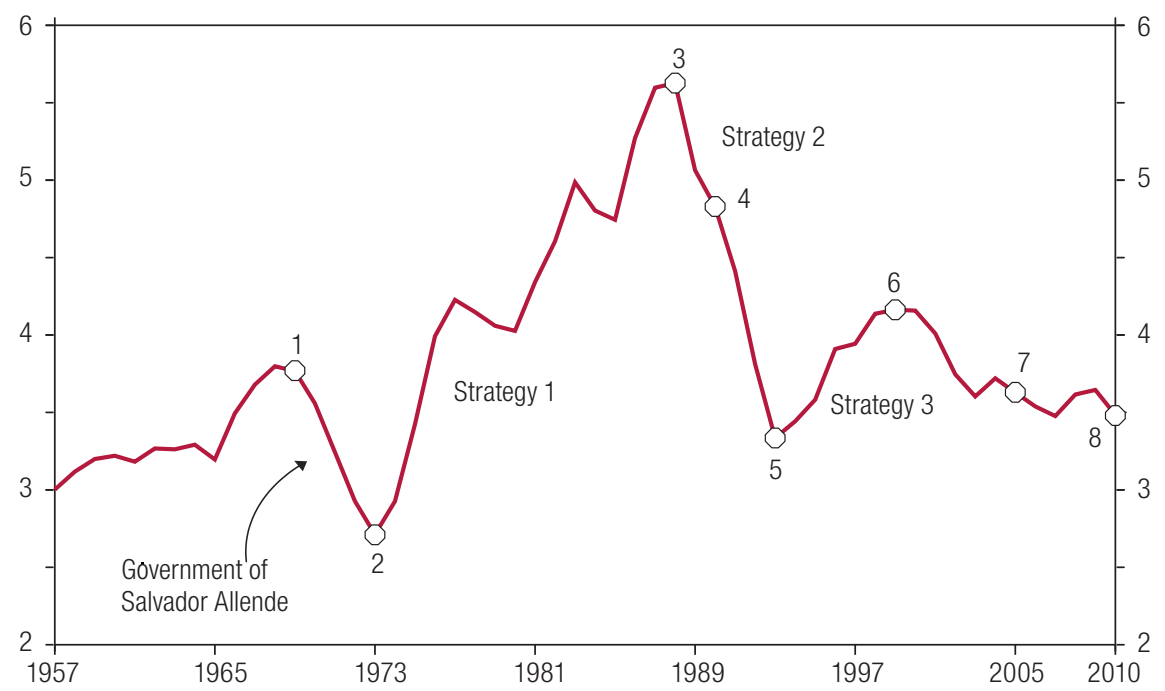

Source: Prepared by P. Jervis and the author, on the basis of Centro de Microdatos (CMD), "Encuesta de Ocupación y Desocupación en el Gran Santiago 2019”, Faculty of Economics and Business, University of Chile, 2020 [online] http://documentos. microdatos.cl/Encuestas/Ocupacion/OcupacionDesocupacion?C=T1

Note: $1 . \quad$ Election of Salvador Allende.

2. Strategy 1 (following coup d'état).

3. Strategy 2 (from plebiscite of 1988 to start of second centre-left government).

4. First democratic government (centre-left coalition).

5,6 and 7. Strategy 3 (consolidation of inequality during the following three centre-left administrations).

8. First democratic right-wing government in more than fifty years. Triennial moving averages ${ }^{20}$

\footnotetext{
19 See also figure 9.

20 For a video that explains the nature of the Palma ratio as a new inequality index, originally published in the Washington Post, see Uncounted, "The Palma" [online] http://uncounted.org/palma/. See also [online] https://www.youtube.com/watch?v=wY9XFQAMcA\&feature=youtu.be. The World Bank (2016) composed a related and similar statistic, the "Palma premium", derived from the Palma ratio (since it primarily indicates the direction of the change in inequality).
} 
The oligarchy's remarkable success during the first few years of strategy 3 tends to confirm my hypothesis that neoliberalism may well have become one of the most effective technologies of power ever. In Latin America, neoliberal ideology — with its extremely successful re-legitimization of capitalbecame shorthand for the art of getting what you want: legitimization of obscene and inefficient levels of inequality within a democracy. Or, in the language of game theory, it became a technology of power capable of transforming a particularly asymmetric set of distributive strategic choices and the corresponding unilateral payoffs into something resembling a Nash equilibrium in a democracy, albeit a low-intensity one. This was achieved by convincing the majority that it was futile to try to challenge this while the all-too-powerful top income players (who owned the playing field, had control of the ball and wrote the rules) kept their strategy unchanged.

It was futile to challenge this not just because the chances of success were minimal (given the distorted nature of the setting in which the game was being played), but also because a majority had to grasp that their meagre payoff was just their lot in life. In any case, under the prevailing international and domestic scenarios, this type of neoliberalism was the only workable option. Furthermore, as Adorno (1951) reminds us, domination is much more effective if the oligarchy can delegate the violence on which the domination is based to the (centre-left) dominated themselves.

As a result, the distributional game even ceased to be one of "chicken" and became one in which this Nash equilibrium around strategy 3 - so improbable in a democracy - was possible, mostly through ideological conviction. The fact that neoliberalism as a technology of power could do this without needing to employ crude old-fashioned forms of social conflict resolution was the most remarkable. In other words, the oligarchy was finally able to achieve in a democracy what was only possible in dictatorship previously.

This was an enormous achievement, while it lasted. When the major once again challenged this Nash equilibrium built around the elite's favourite strategy, in many countries the elite switched strategy and sought alliances with a range of parallel causes, such as cultural wars, racism, misogyny, nativism, xenophobia, nationalism, moralistic religious agendas and any populist cause. On occasion assistance even came from organized crime. The support of the corporate and financial elite for policies such as those of Trump and Bolsonaro is archetypal.

In Chile, however, these auxiliary causes gained little traction; moreover, a somewhat more politically sophisticated elite could still get its way with traditional forms of domination, such as the power to continue debilitating the rest of society by imposing an increasingly insecure life on workers and the State. These actions represented the stick, while the carrot was the promise that the payoff for the majority would eventually improve thanks to trickle-down effects. And they were told that they should be reasonable because there was no feasible better alternative for them.

Ultimately, the elite smartly chose not to oppose the new agenda of values of the centre-left administrations - which included the right to abortion and legal equality of homosexual personsdespite this going entirely against their moral values. In fact, the right much more vigorously opposed a minor tax reform pursued by the fourth centre-left government than the bill to legalize abortion at that time in three situations. The latter was mere lip service.

As a result, Chile was able to do away with the image of a banana republic in which the oligarchy needed nefarious individuals, in politics and in the management of the economy, to achieve its aims. In its new and more sophisticated domination model, military regimes -the traditional hedge against the threat from the majority - could become obsolete. Neoliberalism in its most sophisticated form.

The rapid economic growth during this period (that of strategy 2 and the start of strategy 3 , see figure 8) gives support to Díaz Alejandro's (1983) anti-fundamentalism hypothesis, perhaps the greatest contribution of any Latin American to economic theory: that in terms of economic policy success, the nature of the policies is as important as the degree of support that they attract. 
Meanwhile, most of my colleagues spend their lives discussing the absolute merits of their proposals, ignoring this simple truth. But when ideology alone is the leitmotiv of so many ideas...

From this perspective, the real challenge for the capitalist elite was that in order to sustain strategy 3 - and maintain that degree of support - it had to continue to deliver a high level of economic growth and trickle-down. That is, in order to continue to "manufacture consent" (Herman and Chomsky, 1988) this elite needed to show that its model could deliver sustainable progress and well-being.

However, reality inevitably caught up with strategy 3 , as in a deregulated capitalist economy with such few compulsions (especially from the market), growth was bound to decelerate owing to the dominance of "easy" rent, and with it (in light of persistent inequality) so did the trickle-down effects. ${ }^{21}$ Thus, GDP and productivity growth both slowed suddenly, particularly the latter, despite very favourable external conditions from 2002 onward (especially export prices and easily accessible cheap debt). In fact, productivity growth decelerated from 3.9\% per year during the golden years of this model (between 1986 and 1998 ) to just $0.4 \%$ in the decade before the social unrest (see figure 8).

There is little doubt that in terms of the trickle-down effect and the well-being of the majority, strategy 3 failed miserably: in a country that had achieved a per capita GDP of US $\$ 15,000$ (US $\$ 25,000$ at purchasing power parity; World Bank, 2020) such a degree of inequality meant that in the final stages of strategy 3 , the Chilean median net wage was not high enough to bring a family of four above the poverty line. And, as expected in this type of scenario, this median hides a huge gender gap: on average, women earned $28 \%$ less than men, meaning that in this case almost two thirds of these households would find themselves in such a situation. ${ }^{22}$

Bearing this in mind, a surprising aspect of this most unlikely of Nash equilibria achieved in strategy 3 -and in a democracy - is that while it was in effect, the majority could have quite feasibly improved its payoff if only it had agreed (while maintaining a minimum of collective action) on a different strategy. But, despite still having the support of half the population, the centre-left political parties were unable to rise to this challenge.

In fact, the idea that there was no alternative was deeply ingrained in the hegemonic consensus around strategy 3 and it synthesised the foundation of the Anglo-lberian-style neoliberal discourse. This idea (which became taboo) had an amazing paralysing effect on the "new" left and on the majority of the population.

In Freudian parlance, the totem built around the supreme power of deregulated markets, giving them an almost supernatural significance - as a symbol erected as the emblem of the neoliberal tribe, which had been converted to a kind of animistic religion - coupled with the taboo against even imagining alternatives (after all, it was the end of history!) is one of the most effective ideological tricks ever.

Surely Gramsci must have felt vindicated. In a democracy, distributive struggles are chiefly won or lost at the level of ideology (supported by the power of social mobilization). Fundamentals? What fundamentals?

Also, as Albert Einstein emphasized (and Poulantzas (1975), following in the footsteps of Althusser, later theorized), even in natural sciences "Whether you can observe a thing or not depends on the theory which you use. It is the theory which decides what can be observed." ${ }^{23}$ And in economics this theory will also suggest the range of options for the econometric specification; and the circle can easily be closed, as in traditional econometric testing there is the problem of "too big to fail" -i.e. in very large samples, $p$-values decline quickly to zero. This can lead researchers to erroneously claim that the econometrics support hypotheses of no practical significance.

\footnotetext{
${ }^{21}$ On why capitalism needs markets that generate compulsions for its dynamic, see especially Wood (2002) and Khan (2005).

22 See Durán and Kremerman (2020).

${ }^{23}$ Quoted in Heisenberg (1971, p. 63). Further "[...] as Einstein has emphasized, [...] deduction in [scientist's] method runs not from facts to the assumptions of the theory but from the assumed theory to the facts and the [...] data. Consequently, theories have to be proposed speculatively and pursued deductively with respect to their many consequences so that they can be put to [...] tests. In short, any theory [...] makes more [...] philosophical assumptions than the facts alone give or imply (Northrop, 1958).
} 


\section{The strengths and weaknesses of strategy 3}

One of the most significant questions concerning all of this is why strategy 3 could not be sustainable. Starting with its ideological aspects, the strengths and weaknesses of some of the ideas in the neoliberal discourse are nothing new. For example, they were already evident in an argument by Callicles (a character in Plato's dialogue Gorgias): "It is natural and just for the strong to dominate the weak, and ... it is unfair for the weak to resist such oppression by establishing laws to limit the power of the strong." 24

In Callicles' opinion -as in the neoliberal critique of the post-war social democratic welfare state-, the problem (and what had to be reversed) had been that "the stronger, more aggressive and domineering by nature, had been defanged and domesticated by the new legal institutions of the weak demos." 25

Calicles also tries to talk Socrates out of philosophizing:

For philosophy, Socrates, if pursued in moderation and at the proper age, is an elegant accomplishment, but too much philosophy is the ruin of human life. Take my advice, abandon argument. Learn the philosophy of business, and acquire the reputation of wisdom. ... Cease, then, emulating these paltry splitters of words, and emulate only the man of substance and honour, who is well to do. ${ }^{26}$

In sum -in the same way that the capitalist elite liked to preach to the "new" left during the transition to democracy - quit philosophizing, abandon argument, get real, do an MBA. It also helps if the rest of society can be convinced that the "dissident" camp was solely made up of pedantic doctrinaires.

The debilitating component of this discourse for the progressive forces vulnerable to the neoliberal pandemic is that abandoning philosophy and argument really meant ceasing to think critically. ${ }^{27}$ The problem with critical thinking, of course, is that it is a distancing, even debilitating, activity. It distances us from conventions, from established assumptions and from settled beliefs. It takes what we know from familiar, unquestioned settings and makes it strange. And it does so not by just supplying new information, but by inviting and provoking a new way of seeing.

The risk is that once the familiar becomes strange, it is never quite the same again. However unsettling, there is no way back; it can never be un-thought or un-known. And as many of the left in Latin America know only too well, there are also huge risks involved, both political and personal. One way to avoid these risks (particularly after so many disappointments and so much terror) is through evasion: scepticism. Although, as Immanuel Kant (1998) reminds us, a period of scepticism can be a resting place to reflect upon previous dogmatic wanderings, to remain there is simply to give up on moral reflection.

The point here, of course, is that - despite the oligarchy's delusions of supremacy deriving from some moral right they convinced themselves they had- the stronger are not so because of nature but because of the environment. This is a core issue of the Darwinian insight into progress whereby a subset of members of a population may come to flourish relative to other members simply because they possess a feature, which others do not, that may render them better suited to some specific local environment. The question of the intrinsic worth of those who flourish most is part of this story (Lawson, 2003).

\footnotetext{
${ }^{24}$ See [online] https://www.gutenberg.org/files/1672/1672-h/1672-h.htm.

25 lbid.

${ }^{26}$ Ibid.

27 See Palma (2016b).
} 
This leads to a crucial component of my understanding of the deeper meaning of neoliberalism: a conscious and deliberate attempt to create a specific and artificially constructed economic environment that favours those features that capital possesses and others do not. An environment in which a mobile and malleable agent could achieve unassailable dominance, the success of which then also creates a seductive force that feeds this ideology.

Following on from the dilemma presented by Hirschman (1970) between exit, voice and loyalty, it could be argued that one reason for the capitalist elite's dominance is, in that scenario, they are the only ones with a credible exit strategy: easy access to mobile financial assets provides an feasible exit strategy. Hence, the threats they make in the distributional game are even more credible under that scenario. Here we can consider the metaphor of someone playing in a football match who tells the other players that either he will play the role of centre forward or he will go home and take his ball with him. Surely this is not the best scenario for building an effective team.

Another metaphor would be a puzzle in which a few large pieces can freely decide what shape they would like to take, while the rest would have to change their shape in order to fit. Or, according to the great Argentine cartoonist Quino, it is like a game of chess in which the oligarchy can checkmate its opponents whenever it likes, whatever its position on the board, which also would make the game rather boring - and the winner easy to predict. $^{28}$

However, at least having an easy exit strategy is precisely what helps Latin American oligarchies to become more democratic - they can take the risk as in the new international order they no longer need to be geographically tied through fixed investments (such as land in the past). ${ }^{29}$

Although the core of their accumulation will always be their home country (such as the purely extractive side of commodities or domestic finance) - it being difficult to find other places that offer these levels of returns - they can now conveniently operate in a geographically diversified portfolio. Thus, the more money they have in tax havens, the nicer the mansions in Palm Beach (hopefully as close as possible to Mar-a-Lago) and the more investments they have in neighbouring countries, the more credible the threats in the national distribution game.

In Chile, for example, and according to balance-of-payments statistics, the assets of the international investment position of the financial and non-financial private sector (not counting private pension funds) reached US\$ 383 billion in 2018 - about a third larger than that year's GDP (Central Bank of Chile, 2020). The foreign currency component of overall debt of non-financial corporations reached one third of GDP (about US\$ 100 billion) - with the exception of China, the largest among all emerging economies (as a share of GDP) (Avdjiev, McGuire and von Peter, 2020). However, as opposed to China, there is little to show for it in terms of domestic investment, technological absorption, product diversification and productivity growth, because instead of investing at home, most of these funds were used to finance capital flight in the form of shifting productive capacities to neighbouring countries.

Hence the assets emerged abroad while the debts were kept at home, with, as they have learned from history, the implicit government guarantees to which they have become accustomed.

This "development" strategy may already be obsolete, and has been for some time, but until the social uprising in 2019 it was supported by an odd political settlement, characterized by the interaction among an insatiable capitalist elite - but one that was risk-adverse in production matters, or as Keynes would say, lacking in "animal spirits" - a captured progressive intelligentsia, passive citizens and a social imagination that had been paralysed by the absolute certainties of the new prevailing hegemonic ideology, the ghosts of the past and the disasters of alterative experiments in the region (Palma, 2016a).

\footnotetext{
${ }^{28}$ See (available in Spanish only) [online] http://ajedrezenlaunla.blogspot.com/2012/04/quino-y-el-ajedrez.html.

29 See Boix (2003) and Palma (2019a).
} 
Another helpful component for domination by the oligarchy in all this is the fact that in the Ibero-American tradition, societies are often run by huge State apparatuses of faceless bureaucrats prepared to passively follow whatever ideology is the order of the day, no matter how economically inefficient these ideologies may be. The civil service in these countries is starkly different from Weberian ones, such as that seen in the Republic of Korea, Taiwan Province of China or Singapore (among other examples).

In fact, a paradigmatic example in Chile of this Ibero-American syndrome of faceless bureaucrats is the way in which the Comprehensive and Progressive Agreement for Trans-Pacific Partnership (generally known as TPP-11) was negotiated by the relevant bureaucrats, ${ }^{30}$ who seemed to be convinced that their professional role was merely to follow the commandments of the dominant ideology. As Primo Levi (1986) emphasises, the truly dangerous people are "the functionaries ready to believe and to act without asking questions".

In short, in strategy 3 there could be only one distributional winner, a rapid rate of economic growth in the 1990s, the trickle-down gains from multiple financial bubbles (including residential real estate) and easy access to credit initially helped confirm the potential of strategy 3 , and facilitated popular support for the discourse of deregulated market supremacy.

This support even continued after the economy slowed and the trickle-down dried up. So much so, that right-wing parties even won a presidential election for the first time in over half a century, after more than a decade of economic deceleration. It seems that the memories of successes last longer than those of failures, in the style of a system of adaptive expectations, whereby the former (successes) tend to create a longer-lasting memory.

\section{The limitations of rent-seeking capitalism: from strategy 3 to strategy 4}

As I said in the dedication of this article to Maradona, and as Freud taught us, our life force mixes with our instinct for self-destruction. In Chile, as in the rest of the world that is captivated by the absolute certainties of neoliberal ideology, the paradise for the elite linked to strategy 3 was temporary (while episodes of hell seem to be slightly more resilient). Because of its very nature, the elite did not really have a high probability of winning indefinitely with this strategy.

In the words of Abraham Lincoln, the Achilles heel of strategy 3 was that "you can fool some of the people all of the time, and all of the people some of the time, but you cannot fool all of the people all of the time" that there is no alternative. The deceleration of growth and the trickle-down effect would ultimately play a crucial role in this. The social uprising in October 2019 finally sent strategy 3 to its resting place. It had achieved its goals for the elite, but had become counterproductive, and was finally drowned by a tsunami of discontent.

The key question is why the success of strategy 3 was also its worst enemy. In my opinion, the crucial point may be found in Ricardo's work: the natural limitation of this amenable rent-seeking capitalism (which, in Palma (2019b) I called "cosy-capitalism") is that the capitalist elite starts taking cosiness for granted. The supremacy of "easy" rent (at the expense of operating profits for doing something that is of use to society) makes investment, product diversification, technological absorption, productivity growth and so on, become optional extras (see figure 8). For the elite, their huge share of national income becomes a source of enjoyment (including the financial casino and capital flight), rather than the fuel that powers new engines of productivity growth.

30 See Palma (2018). 
There also needs to be a continuing supply of poor (either nationals or imported as immigrants), because as the epigraph from Voltaire tells us, the comfort of the rich depends on an abundant supply of poor.

As Keynes (1920) said, when analysing the success of late-nineteenth century emerging economies, such as Germany and the United States "The new rich of the nineteenth century ... preferred the power which investment gave them to the pleasures of immediate consumption. ... Herein lay, in fact, the main justification of the Capitalist System. If the rich had spent their new wealth on their own enjoyments, the world would long ago have found such a regime intolerable".

Intolerable indeed! That is exactly the greatest challenge that neoliberalism faces as a technology of power: it wants to achieve the opposite of all of that, but transforming that which is (inevitably) intolerable into something tolerable, and doing so within democracy.

Figures 1, 4 and 7 summarize the distributional outcome of strategy 3. Figure 8 shows their impacts on the real economy: in "cosy" and rent-seeking capitalism, cosiness for the elite and the challenges of dynamic markets do not mix well. Cronyism, or the ever closer and mutually advantageous relationships between business leaders and centre-left government officials, did not help either, as it enabled transformed strategy 3 into an extreme version of North's "limited access order" capitalism. ${ }^{31}$

Figure 8

Chile: GDP, employment and productivity, 1950-2019

(Percentages)

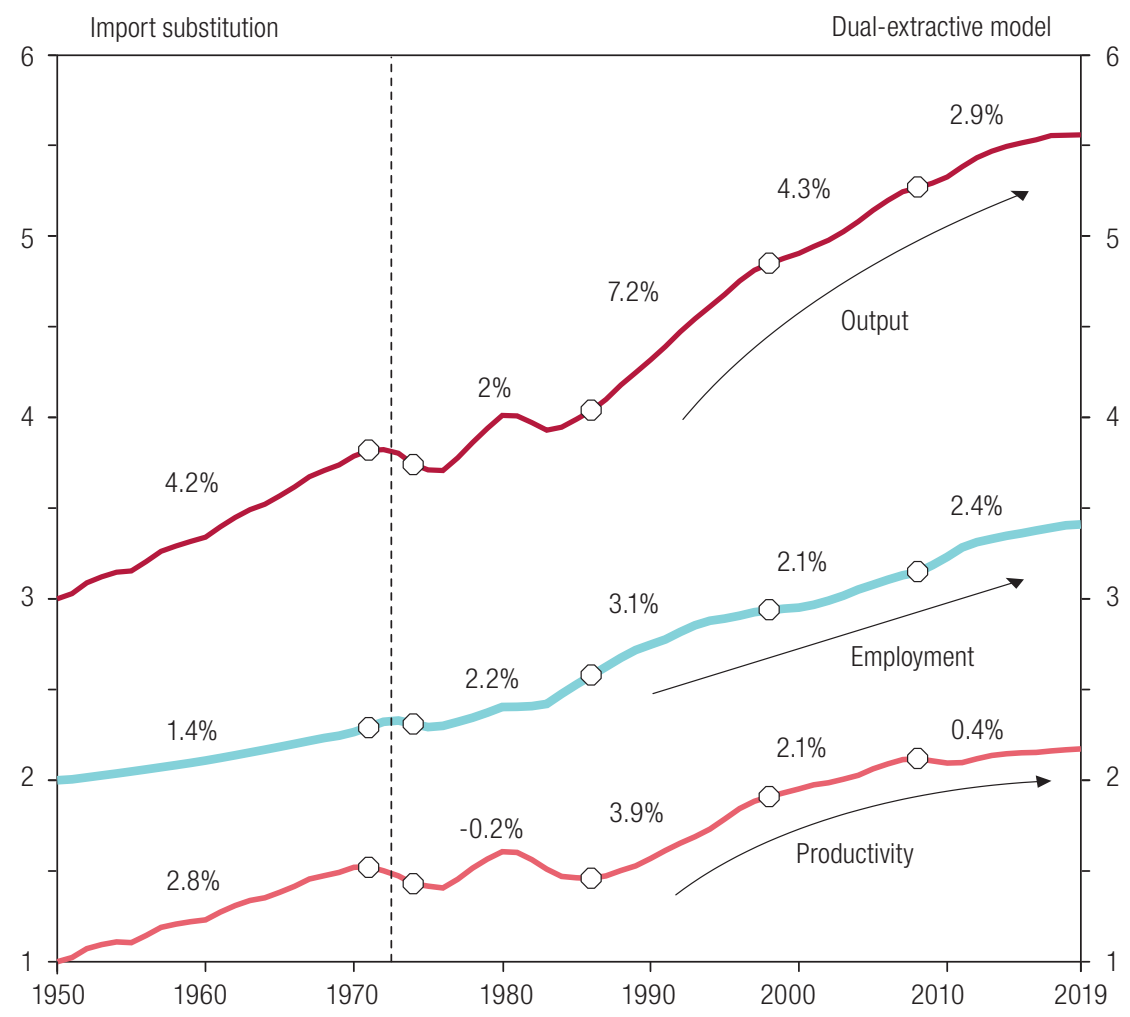

Source: The Conference Board, "Total Economy Database: key findings", 2020 [online] https://www.conference-board.org/data/ economydatabase/.

Note: Each series is an index number (log scale), with base 1 in 1950 for productivity, base 2 in 1950 for employment and base 3 in 1950 for GDP. The dual-extractive model is the development strategy followed by Chile since its neoliberal economic reforms. ${ }^{32}$ Productivity refers to output per worker. Three-year moving averages.

\footnotetext{
${ }^{31}$ North and others (2007).

32 See Palma (2019b).
} 
Figure 8 confirms the idea that although neoliberalism may well have become one of the most effective technologies of power ever, it had its Achilles' heels: its preference both for an economic scenario in which there were few market compulsions for big capital. The supremacy of inefficiency rent, such as that from market failures and distortions, also needed a "subsidiary" State, which instead of "disciplining" the capitalist elite (for example, to invest a large share of their income in activities with significant potential for long-term productivity growth), is instead disciplined by the elite. In other words, as a company manager might say, Chile become a market economy in name only (Lamarca, 2009). "Capitalism" of this kind (easy rent for the elite, capitalism for the rest) inevitably led to stagnant productivity growth. In the country, average annual productivity growth was just $0.4 \%$ over slightly more than a decade before the social unrest of 2019, in line with the average for the region since 1980. What sets Chile apart from the rest of the region is essentially that it had its golden extractivist age in the 1990s, but wasted that energy later.

If capitalism is what you want, as Keynes insisted, you must save it from this type of purely rent-seeking capitalists by implementing alternative strategies for national development and autonomy. To do this, a State is required that seeks to inject dynamism into an economy (Keynes, 1936, vol. I), and helps to coordinate investment (chapter 12). In other words, a disciplinatory State, rather than a chastised State. This is the key to emerging Asia's success. ${ }^{33}$ But in the Chile of strategy 3, with its chastised and subsidiary State, no such development agenda was in sight.

As figure 8 shows, GDP growth decelerated rapidly during the period of strategy 3, almost entirely due to the collapse of productivity growth (from an average of 3.9\% per annum to just $0.4 \%$ ); that is, to the point that creation of cheap jobs (mostly in traditional service sectors and construction, which accounted for $80 \%$ of the labour force, and with their traditionally low potential for long-term productivity growth) became the only driver of GDP growth for this capitalism that was increasingly "cosy" for the elite. The political and economic impact of this was overwhelming, proving Krugman (1994) right: "productivity [growth] isn't everything, but, in the long run, it is almost everything".

So much so that when the country inevitably ran out of cheap labour - as traditional services and construction had absorbed it at a rate between two to three times higher than the (low) population growth - the capitalist elite faced a historic crossroads. This was exactly the same crossroads as had been faced by every current developed country at a similar level of development. The crossroads offered two options. The first was to confront the lack of cheap labour, and the inevitable rises in wages, increasing productivity by updating the development strategy -in the case of Chile, by modernizing its dual-extractive model by searching for new engines of productivity growth, such as the industrialization of commodities or a green new deal. The second option was to simply opt for "more of the same" by filling the labour market with cheap labour through a new policy of mass immigration from neighbouring countries.

There are no prizes for guessing what happened to the cosy and amenable capitalism of strategy 3. Instead of accelerating productivity growth, they preferred "more of the same", with an abundance of cheap labour. The mass influx of immigrants that followed (so far equivalent to about $10 \%$ of the labour force) was generated by incentives from Chile, not by external factors (pull factors, not push factors). That is to say, it started with deliberate changes in immigration policy, not with political disturbances in neighbouring countries.

Most immigrants came legally, by plane into Santiago's main airport (often on special chartered flights). This phenomenon created a paradise for human trafficking gangs, which organized the logistics, transport and paperwork, then profited from the horrific conditions in which many of these immigrants ended up living in Chile. All immigrants needed to get a tourist visa when arriving in Chile was the return

${ }^{33}$ On how Republic of Korea did this during its process of industrialization, see Chang (1993); for Taiwan, Taiwan Province of China, see Wade (2003). For a summary, see Palma (2019a, figure 22). 
plane ticket, an identity document, and a little cash (to prove that they were "tourists") -all of which were often provided by the very same trafficking gangs. A labour contract -again, sometimes provided by the same gangs - would then suffice to swap a tourist visa for a work and residence permit.

Moreover, no one pushing for the new immigration policy seemed to have worried about the lack of housing or the limited availability of health services, education, transport, and all the basic services which would be desperately needed by these immigrants (Palma, 2019b).

Hence, a growth model based on an abundance of cheap labour and no productivity growth (and continuous horizontal diversification abroad in production matters) could be maintained. Turning again to Voltaire, the comfort of the rich also depends upon an abundant supply of the poor in the production sphere.

It was precisely this "more of the same" that meant the neoliberal model was totally unable to update itself when its existing engines of growth (mere extraction of commodities and cheap services) had run their course. "Cosy-capitalism" - and its limited access order - had become self-destructive. The oligarchy has no one but itself to blame for strategy 3 having become contrary to their own long-term interests.

This inertia of insisting on "more of the same" - i.e. the resistance of the status quo to changes in its state of rest - and calm inaction reminds us of Conrad novels in which, as in so many sea stories, the main enemy of creativity is stasis. It is, in fact, the deadliest thing of all (Segal, 1997).

Finally, and as opposed to what household surveys indicate (figure 7 and Ministry of Social Development and Family Affairs, 2020), new tax data indicate that strategy 3 was far more distributionally successful for top earners than had been believed so far - casting further doubts on Chile's supposed declining inequality (see figure 9).

Figure 9

Chile: shares of pre-tax income of the wealthiest $1 \%$ and $10 \%$, and post-tax and -transfers Palma ratio, 2000-2019

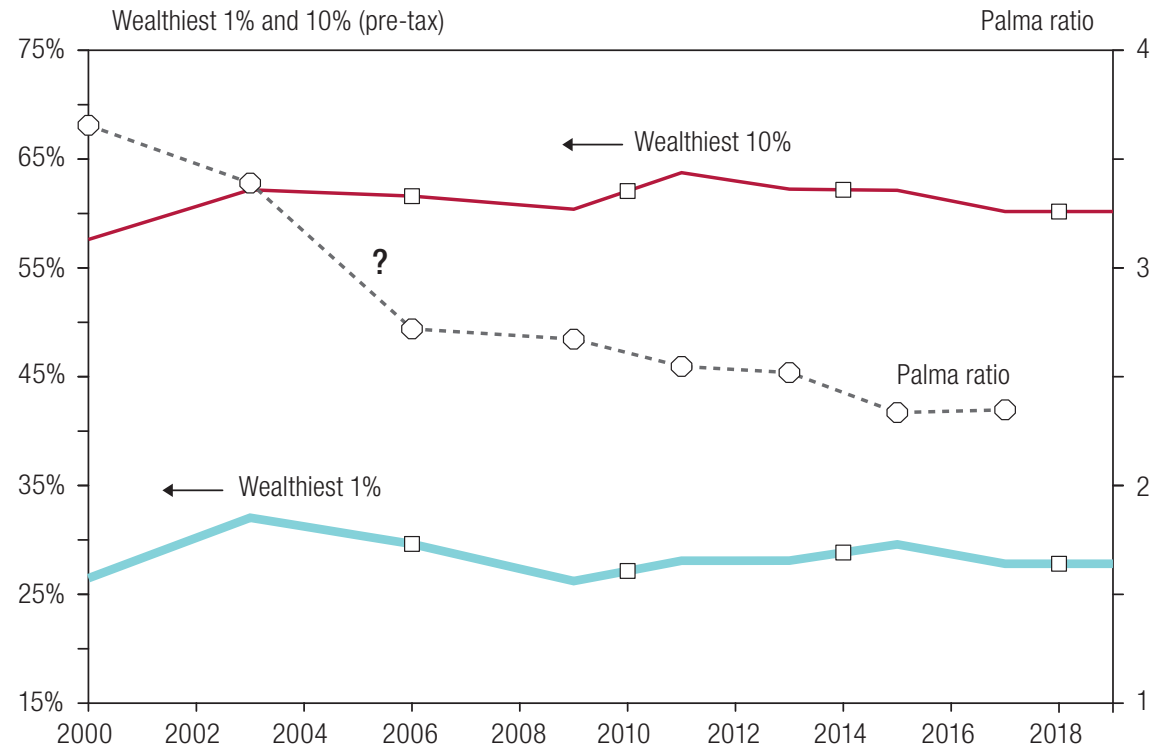

Source:World Inequality Lab, World Inequality Database, 2020 [online] http://wid.world/, on the basis of M. De Rosa, I. Flores and M. Morgan, "Inequality in Latin America revisited: insights from distributional national accounts", Technical Note, No. 2020/02, 2020 (for pre-tax income); and J. G. Palma, "Behind the seven veils of inequality: what if it's all about the struggle within just one half of the population over just one half of the national income?", Development and Change, vol. 50, No. 5, September 2019 (for the Palma ratio).

Note: Circles indicate years that the main household survey (CASEN) was carried out; squares indicate presidential periods. 
If the share of the wealthiest remained basically stable during this period, a drop in the Palma ratio of this nature (especially towards the end of the presidency of Ricardo Lagos, see the question mark in figure 9) would have needed an increase of the share of the bottom $40 \%$ of about twice the level reported in household budget surveys. It is difficult to believe that in a country with such a low and regressive system of taxation, the supposed post-tax drop of the income shares at the top, as reported in the surveys, is anything but the growing inability of these surveys to capture the income of the rich in this growingly financialized - and "tax-havened" world.

In sum, even though strategy 3 did become an abject failure in productivity matters, in the medium term it was remarkably successful for the rich in distributional ones - until an outburst of popular discontent put a sudden end to it with a display of social power not seen in Chile since defeat of Pinochet in his 1988 plebiscite. The power of the young (enraged by the hopeless future on offer under this strategy), and the feminist movement (which had had enough of gender abuse and discrimination at every level) ${ }^{34}$ - not helped by violence from a large group of young people who have marginalized themselves, who neither study, nor work nor look for work - broke the neoliberal ideological spell: the emperor (who proclaimed "there are no other options") had no clothes.

\section{Strategy 4: from the elite's "preferred" distributional strategy (number 3) to a (somewhat desperate) search for peace in society through a substantial increase in social protection (towards the European "new social democracy")}

Although this new distributional switch involves many issues, there can be little doubt that the key one is economic reality making it clear that in strategy 3 the supremacy of easy rent led to a lack of production growth. Also, new technologies of social communication have helped improve social cohesion among the majority and have amplified their "voice" (as referred to by Hirschman). Previously, the elite's greater capacity for collective action due to its internal cohesion contributed to it having the upper hand in games of chicken; but new communications technologies have changed that. As the social unrest in Chile demonstrates, these new technologies have been a game changer.

The explosion of social unrest in October 2019 was quickly followed by the emergence of the pandemic, which provided a distraction from the social discontent for a while. However, as poverty and unemployment grew rapidly, while the centre-right government struggled to respond, this distraction was short-lived. The fact that almost all the great fortunes continued to expand as in the best of times (helped by the "perpetual mania" of the financial casino (Palma, 2020b)) became insulting to the majority of the population. When the plebiscite was finally held in October 2020 on whether to change Pinochet's Constitution, it gained $80 \%$ support.

From the perspective of this work, one of the key impacts of the pandemic was to throw all kinds of inequalities into stark relief. For example, while in a middle-class neighbourhood (Ñuñoa), the two main reasons for requesting a permit to leave the house during lockdown were to go to the supermarket and to walk their (pedigree) dogs, in a working-class neighbourhood (La Pintana) these

\footnotetext{
34 Its slogan, "El Estado opresor es un macho violador" (The oppressive state is a rapist macho) said it all (https://www.youtube. $\mathrm{com} /$ watch?v=tB1cWh27rml).
} 
permits were mainly requested to attend funerals and visit relatives in penal institutions. In addition, low Internet coverage (13\%) forced people from the neighbourhood to leave their homes even if they could work or study from home.

The combination of the explosion of discontent and the pandemic led to great anxiety - and in many cases outright panic - among the elite that Chile would once again be politically unmanageable as soon as there was some resemblance of normality. For a respected right-wing analyst, for example, the greatest fear was neither the coronavirus, which would pass although it would claim many lives, nor the imminent economic debacle, which would also ultimately end. His greatest fear was an unmanageable social group that had abandoned the basic rules of communal life. ${ }^{35}$

Faced with these uncertainties and challenges, some politicians and business leaders saw the discourse of European "new social democracy" as a way out of their strategic impasse, hoping that it could ensure a minimum of social protection and peace (strategy 4).

For example, the presidents of the main business associations, contradicting everything that they had preached for generations (especially since the neoliberal reforms), began to idealize a European-style new social democratic model. ${ }^{36}$ Even some intellectuals from that political orientation began to publish social democratic manifestos to prevent future governments from moving from one social uprising to the next (Waissbluth, 2020). A former finance minister of Chile's current right-wing government, who is now a presidential candidate, expressed a similar opinion. Another candidate for the next presidential election (one of the "Chicago Boys" and a former favourite of Pinochet) also, for the first time, defined himself as a social democrat -and even said he was in favour of a stronger State capable of guaranteeing social rights (El Mercurio, 2020).

Not surprisingly, some on the "new" Left were furious, claiming that this was a serious infringement on their intellectual property rights!

Strangely, it is the inconsistencies between the economic and social agendas of the European new social democracy (see Palma, 2019a) that made strategy 4 so attractive to those who sought inertia in the status quo, but with peace in society (see annex A2). While the economic agenda is seemingly aimed at delivering more of the same, the new social agenda could give a new lease of life to their now fragile neoliberal model. Furthermore, they have an ace up their sleeve: in this financialized world, instead of having to pay for the extra social protection with new taxes, additional public sector borrowing can always save the day. Therefore, for the business community a switch to strategy 4 could be a win-win situation; it could re-establish the legitimacy of the neoliberal rentier model by making it a bit more civilized, and public bonds (instead of taxes) could finance the much-needed social peace, fighting poverty and providing a minimum degree of equity. How had this not occurred to them before?

Basically, it would be a way to square the circle: powerful agents could continue to manipulate the product and financial markets at their pleasure (including continuing to extend the market into hitherto unacceptable, even inconceivable, spheres of social life - those that have already generated some of the most inefficient activities in the economy), and deficit spending could facilitate the herd immunity necessary for social peace.

From this perspective, the new strategy makes complete sense, and the dwindling number of people within their group that still reject it are largely driven by the self-destructive power of fundamentalism. The most attractive element for the more enlightened right wing is that this new alternative, together with offering a minimum of social peace and some equality, allows them to maintain the Buchanian aspects of their model, of which Pinochet's Constitution and its "handcuff laws" (agreed with the centre-left during the transition to democracy; see annex A1) are a paradigmatic example. The bill currently in the Senate to support the aforementioned "TPP-11" agreement is another classic example (Palma, 2021).

\footnotetext{
35 See [online] https://www.latercera.com/opinion/noticia/el-miedo/SS57SUH65JGWXEE4VDXJD5N2W4/.

${ }^{36} \mathrm{See}$, for example [online] https://interferencia.cl/articulos/entrevista-juan-sutil-desde-el-punto-de-vista-social-probablementechile-tiene-que-avanzar.
} 
For Buchanan (1993), those who really needed social protection were big businesses and their property rights could only be guaranteed by imposing constitutional guarantees. Buchanan had a rather paranoid view of society, whereby there was an eternal conflict between "creators" (entrepreneurs) and "looters" (everyone else), who would constantly besiege the former. In his work he repeatedly warns of the danger of parasites and predators besieging innovators, who must therefore be given social protection through constitutional limits to change.

As in the rest of Latin America, in Chile this Buchanian influence has also permeated the ideology of the "new" left. Since the transition to democracy they have spared no effort in apologising for their "predatory" past (e.g. having been in favour of agrarian reforms, nationalization of natural resources, and so on). This has also occurred in Chile with the Christian Democratic Party. In the 1960s its first President, Eduardo Frei Montalva, had an economic agenda which was closely coordinated with the social agenda: agrarian reforms and the partial nationalisation of large copper mines went hand in hand with policies for social protection and social empowerment (the famous "Promoción Popular" policy). However, in the 1990s, during the presidency of his son Eduardo Frei Ruiz-Tagle, while the social agenda remained similar to that of Frei senior (although implemented in a more consultancy-intensive way), the economic agenda tried to build a future opposite to the past. And since these agendas pointed in opposite directions, they obstructed each other.

Moreover, the support from most of the centre-left for these constitutional barriers to defend the property rights of "creators" is provided despite the rather uncreative way in which so many of these supposed innovators acquired their assets: by pillaging public corporations and natural resources during the highly corrupt neoliberal reforms, with access to the plunder restricted to courtiers of the regime and relatives of the dictator. ${ }^{37}$

The question, of course, is whether in Latin America this new strategy 4 will achieve its goal of being an effective and sustainable mechanism to make a traditional neoliberal economic agenda compatible with a more civilized (social democratic) social agenda as it has been so far in Western Europe. Asymmetries of this kind are surely more fragile on the periphery than in the centre.

Also, strategy 4 may have arrived to too late in Latin America, as did the aristocratic concessions in late eighteenth-century France. Latin American oligarchies will surely need "fancy footwork" and the appropriate collective action to make this new strategy work. It remains to be seen how all of this will play out.

\section{Conclusions}

This paper tries to answer the question of why it is so easy for the rich to stay rich, no matter what the rest of society wants. In analytical terms, it contrasts the neoclassical vision, which stresses that the huge inequality in Latin America is a result of natural interactions between a number of "fundamentals" that are essentially economic and somewhat exogenous, and the Ricardian vision, in which the key lies in the structure of an antagonistic distribution conflict between rentiers, capitalists, bureaucrats and workers. This reflects both the particular interactions between power structures and market failures, and the capacity of a society to choose between alternatives in a world of multiple equilibria. In this, history, politics and institutions are equally as important as economic "fundamentals" or even more important.

Within this perspective, the analytical challenges is how to draw back the veils obscuring these interactions and distorting our vision of the self-constructed nature of its inequality.

Therefore, rather than thinking (as in most neoclassical narratives) about the possible concrete effects that known factors may have on inequality (e.g. technology, social mobility, education, and so on), it would be more illuminating to try to understand the concrete expressions that these factors may

${ }^{37}$ See, for example, Mönckeberg (2015), Gárate Chateau (2012) and Palma (2013). 
find in actual situations of inequality, such as Chile's. In fact, some of the pieces of the distributional puzzle may well be the same in different circumstances, but the way they fit together may differ - sometimes significantly.

As I first discussed in Palma (1978) and later developed in (2016b), the analytical challenge in subjects such as inequality is not about building "mechanico-formal" theories that supposedly explain it all in a generic way. It is about developing methodologies for the analysis of concrete situations of phenomena such as inequality (the main aim of this study).

It is obvious that the capitalist economy tends towards a greater level of inequality and not just because of neoclassical issues such as Piketty's ${ }^{38}$ " $r>g$ ", but because the elite, with its material power, ideological hegemony, strategic flexibility and internal cohesion, has the option to construct several routes to get the same advantages in the distributional struggle. It is also obvious that we are embarked on a process of growing internationalization and financialization, that societies are divided into key antagonistic groups, and that the particular is to a certain extent conditioned by the general. Essentially, the question we must ask ourselves is therefore why with these premises we have not gone beyond a partial - and therefore abstract - characterization of the phenomenon of inequality. The next step has yet to be taken: connecting the analysis to the specific, real-world situations of inequality.

A key lesson from the complex Chilean experience of distribution is the insight it provides into the fundamental problem with neoclassical thinking: it has never been able to break away from its original sin, of considering income distribution to be the natural (and somewhat mechanical) outcome of the relative value of marginal productivities (Solow, 1956). Furthermore, in that analysis, technology, preferences and factor endowments are assumed to be "givens" and history, institutions and politics are optional extras.

For example, although Chile has the same per capita GDP and the same average wage as Croatia (World Bank, 2020), it has a median wage that is only half Croatia's (Durán and Kremerman, 2020). Surely this is not because some predetermined "fundamentals" have forced Chile to have such wage inequality. Here, the core issue is of choices between real alternative means of doing things. There has been enough assuming that we are innocent bystanders at the mercy of exogenous distributional forces. ${ }^{39}$ And this choice, of course, is not taken in a vacuum, but within the parameters of the interaction between our history, politics and institutions with some of those fundamentals and market failures and distortions. As previously suggested, the critical factor is the agency, but for any agency to succeed, it must understand the structure.

Surely no predetermined force has compelled us in Chile (with its high middle-income level) to have a median net wage that is unable to bring a family of four above the poverty line. And all this in a country that likes to think of itself as ad portas to becoming a "developed" one - a good example of wishful thinking bordering on the delusional.

In other words, nothing reveals more transparently who we truly are in Chile as a society than the inequality we collectively choose to construct. The bottom line is that in Chile, as in most of the world, we deserve the inequality we have (Palma, 2016a). And this is as self-defining an act as it can be!

For example, Chile spends twice as much as Croatia on education and 50\% more on health care, in terms of its percentage of public expenditure, and its tertiary enrolment is one third higher; it has a much higher rating in Moody's (A1 vs. Ba1), S\&P ( + + vs. BBB-) and Fitch ( $A-$ vs. BBB-); it has a much lower level of corruption in traditional rankings; its State is less "fragile"; and it has a much better balance-of-payments position, and so on, but its Palma ratio is 2.8 (and Gini 48), while in Croatia the Palma ratio is just 1.1 (and Gini 31) (World Bank, 2020).

\footnotetext{
38 Where "r" is the rate of return on capital and " $g$ " is the growth rate of an economy.

${ }^{39}$ For a critique of neoclassical distributional models, and of their econometrics -especially on the use of the Gini index as a dependent variable, leading to misspecification and endogeneity - see Palma (2019a).
} 
Perhaps the fact that its rate of homicides per 100,000 inhabitants (although very low by Latin American standards) is four times higher than Croatia's is a much more telling indicator of how inequality is self-constructed in Chile - and the way in which conflicts in general are articulated - than what rating agencies can tell us about both countries.

Another vital lesson from the Chilean experience is that in countries with artificially-constructed high levels of inequality, most of the routes available to the elite to get the upper hand are associated with an economic inefficiency. Markets are distorted to create excessive inequality and then (with the exception of very specific situations, such as that of Chile in the 1990s) the "excess" does not even return to the economy in the form of production (investment).

Mostly (but certainly not entirely) because of this, these routes or strategies become losing games if played indefinitely. Therefore, the secret for the elite is to be flexible and internally cohesive enough to play a sequence of losing strategies that wins -i.e. Parrondo's paradox. Perhaps Chile's greatest contribution to the analysis of inequality is that both phenomena - the relationship between self-constructed inequality and economic inefficiency, and the paradox - have taken place in a fairly transparent form.

And on the subject of OECD countries, no exogenous force has led them to "bananize" their market inequality (see annex A2, figure A2.1); the crucial issue is taking responsibility for our distributional choices. Germany's market inequality (and that of almost all high-income OECD countries) is not just "reverse-catching-up" with the tropics, but even surpassing almost all of Latin America. Clearly it was their choice, and one that self-defines their current political configuration.

So, life is no longer that easy in high-income OECD countries now, with not only a family to support, but also an oligarchy. It is all too tempting to say "Welcome to the Third World!".

In turn, Latin America's Southern-style distributional situation has thus far proved to be something of a "stationary process": their defensive "fancy footwork" against potential unbalancing events has been up to the task. Political shocks - such as the financial crisis of 1982 when Chile's GDP fell by $20 \%$, unemployment surged to $30 \%$, and half of the population fell below the poverty line, or the impact of the return to democracy - have therefore only had a short-lasting impact (the strength of which has waned rapidly).

Thus, in this "Gattopardian" stationary mode, in the event of destabilizing occurrences, almost everything has been allowed to change so that everything that matters to the elite can stay just as it was. The key question for Chile is whether the same will happen with the October 2019 social upheaval, which is now mixed with the pandemic and the new constitution. Or perhaps it will be the blow that finally has a more permanent effect on the process of accumulation and domination. In short, will these impacts transform everything into something of a "unit root" process, whereby such impacts do not decline in strength over time?

What is at stake is whether strategy 4, and the elite's new social agenda, will be able to repeat the "Gattopardian" trick. That is the "known unknown" of today's Chile and of other parts of the region.

Another mystery is how this oligarchy can be so flexible in its response to distributive impacts, and revise its strategy to revert them, while in economic matters it has been so rigid. Indeed, it is still stuck in a glaringly obsolete 1970s neoliberal model, based on the early, primitive version of the Washington Consensus. If in one sphere they are the masters of "political articulation", in the other they have shown the manoeuvrability of an oil tanker.

The economic challenge that the countries of the region face is a titanic one: as discussed above, the fundamental problem with Latin America's current economic agenda is that it is very hard to reshape the component parts of the structure of an economic system with so little entropy; in other words, if there is a prerequisite that the fundamentals of the status quo cannot be changed, there are 
very few ways to move forward. If those at the top want to continue taking the lion's share for seizing low-hanging fruit, they must expend a lot of energy to "freeze time". As a result, little energy is left for moving towards more flexible structures in which these rigidities can be "disturbed", seeking to rearrange the components into more imaginative (and efficient) structures.

On the subject of "disturbing" rigidities to rearrange components in more imaginative ways, the European new social democracy also faces a key challenge of this nature from its social protection system.

Furthermore, this time the help of the new left is not as useful as it was during strategies 2 and 3 , as this group has lost most of its political clout. As already mentioned, for Adorno (1951), this is no minor point, as domination is so much more effective when the oligarchy "can delegate the ... violence on which it rests to the dominated".

As analysed in Palma (2020a), Latin America is now trapped in what I call a "Gramscian Moment", when the old fades, but the new fails to be born -i.e. when the elite and its "model" lose their legitimacy, but alternative discourses have so far been unable to gather sufficient credibility. In this interregnum, as Gramsci (1992) warns us - and as many in Latin America are experiencing first-hand, especially in Brazil - it is almost inevitable that a "a great variety of harmful symptoms" will appear. Part of the problem is that the region's neoliberal inertia has also stifled its social imagination (Palma, 2016b).

In sum, had the Latin American elite's plasticity in matters relating to its distributional strategy been replicated in the economic sphere, its economy (and more) would not be trapped ever deeper in the quicksand of inertia - my definition of a "middle-income trap" - , of which Chile is a paradigmatic case (Palma, 2019b).

The Freudian opposition between the instinct toward survival and the self-destructive drive seems to play out rather transparently in the spheres analysed in this article - particularly in the recurrent conflict between the Latin American elite's enormous "ability to persist" and its self-destructive rent-seeking drive.

\section{Bibliography}

Acemoglu, D. and J. A. Robinson (2006), Economic Origins of Dictatorship and Democracy, Cambridge, Cambridge University Press.

Adorno, T. (1951), Minima Moralia: Reflections from Damaged Life, New Left Books.

Arantes, P. (2007), Extinção, São Paulo, Boitempo.

Atkinson, A. (2015), Inequality: What Can Be Done?, Cambridge, Harvard University Press.

Atria, J. and others (2018), "Top incomes in Chile: a historical perspective of income inequality" (1964-2015)", Working Paper Series, No. 2018/11, World Inequality Lab.

Avdjiev, S., P. McGuire and G. von Peter (2020), "International dimensions of EME corporate debt", BIS Quarterly Review, June.

Benjamin, W. (1968), Illuminations: Essays and Reflections, San Diego, Harcourt Brace Jovanovich.

Blakeslee, S. (2000), "Paradox in game theory: losing strategy that wins", The New York Times, 25 January [online] https://www.nytimes.com/2000/01/25/science/paradox-in-game-theory-losing-strategy-that-wins.html.

Boix, C. (2003), Democracy and Redistribution, Cambridge, Cambridge University Press.

Bourguignon, F. (2015), The Globalization of Inequality, Princeton, Princeton University Press.

Britton, R. (1998), Belief and Imagination: Explorations in Psychoanalysis, London, Routledge.

Buchanan, J. (1993), "How can constitutions be designed so that politicians who seek to serve "public interest" can survive and prosper?", Constitutional Political Economy, vol. 4, December.

Central Bank of Chile (2020), "Foreign Direct Investment (FDI)" [online] https://si3.bcentral.cl/estadisticas/ Principal1/enlaces/IED/IED_EN.html.

Chang, H. J. (1993), "The political economy of industrial policy in Korea", Cambridge Journal of Economics, vol. 17, No. 2, June.

CMD (Centro de Microdatos) (2020), "Encuesta de Ocupación y Desocupación en el Gran Santiago 2019", Faculty of Economics and Business, University of Chile [online] http://documentos.microdatos.cl/Encuestas/ Ocupacion/OcupacionDesocupacion?C=T1. 
De Rosa, M., I. Flores and M. Morgan (2020), "Inequality in Latin America revisited: insights from distributional national accounts", Technical Note, No. 2020/02, World Inequality Lab.

Díaz Alejandro, C. F. (1983), "Some aspects of the 1982-83 Brazilian payments crisis", Brookings Paper on Economic Activity, No. 2.

Di John, J. (2006), "The political economy of taxation and tax reform in developing countries", Research Paper, No. 2006/74, Helsinki, World Institute for Development Economics Research (UNU-WIDER).

Durán, G. and M. Kremerman (2020), Los verdaderos sueldos de Chile: panorama actual del valor de la fuerza de trabajo usando la Encuesta Suplementaria de Ingresos ESI (2019), Santiago, Fundación Sol.

ECLAC (Economic Commission for Latin America and the Caribbean) (2016), "Tax evasion in Latin America totals $\$ 340$ billion dollars and represents $6.7 \%$ of regional GDP", 1 September [online] https://www. cepal.org/en/news/tax-evasion-latin-america-totals-340-billion-dollars-and-represents-67-regional-gdp.

El Mercurio (2020), "¿Qué significa ser socialdemócrata?: la pregunta que surge tras la sorpresiva definición de Joaquín Lavín”, 24 August [online] https://www.emol.com/noticias/Nacional/2020/08/24/995890/ ser-socialdemocrata-definicion-Lavin.html.

Engel, E., A. Galetovic and C. Raddatz (1999), "Taxes and income distribution in Chile: some unpleasant redistributive arithmetic", Journal of Development Economics, vol. 59, No. 1, June.

Financial Times (2020a), "Pandemic makes world's billionaires - and their advisers - richer", 23 October [online] https://www.ft.com/content/ab30d301-351b-4387-b212-12fed904324b.

_ (2020b), "Eurozone budget deficits rise almost tenfold to counter pandemic", 18 October [online] https:// www.ft.com/content/5579361f-5aac-4cd3-9e93-190fffdc0baf.

Fishlow, A. (1972), "Brazilian size distribution of income", American Economic Review, vol. 62, No. 2, May.

Foucault, M. (2008), The Birth of Biopolitics: Lectures at the Collège de France, 1978-79, New York, Palgrave Macmillan.

Frangie, S. (2008), "The 'political economy of consensus' in post-civil war Lebanon, 1993-2005", doctoral thesis, University of Cambridge.

Galbraith, J. (2016), Inequality: What Everyone Needs to Know, Oxford, Oxford University Press.

Gárate Chateau, M. (2012), La revolución capitalista de Chile (1973-2003), Santiago, Ediciones Universidad Alberto Hurtado.

Gramsci, A. (1992), Prison Notebooks, New York, Columbia University Press.

Harcourt, G. (2015), "Review article: Thomas Piketty, Capital in the Twenty-First Century', The Economic and Labour Relations Review, vol. 26, No. 2, May.

Heisenberg, W. (1971), Physics and Beyond: Encounters and Conversations, Crows Nest, Allen \& Unwin.

Herman, E. S. and N. Chomsky (1988), Manufacturing Consent: The Political Economy of the Mass Media, New York, Pantheon Books.

Hirschman, A. (1970), Exit, Voice, and Loyalty: Responses to Decline in Firms, Organizations, and States, Cambridge, Harvard University Press.

Kaldor, N. (1955), "Alternative theories of distribution", The Review of Economic Studies, vol. 23, No. 2, January.

Kant, I. (1998), Critique of Pure Reason, Cambridge, Cambridge University Press.

Key, E., M. Klosek and D. Abbott (2006), "On Parrondo's paradox: how to construct unfair games by composing fair games”, The ANZIAM Journal, vol. 47, No. 4, April.

Keynes, J. M. (1936), The General Theory of Employment, Interest and Money, New York, Harcourt, Brace and Howe.

(1920), The Economic Consequences of the Peace, New York, Harcourt, Brace and Howe.

Khan, M. (2018), "Political settlements and the analysis of institutions", African Affairs, vol. 117, No. 469, October. (2005), "The capitalist transformation", The Origins of Development Economics: How Schools of Economic Thought Have Addressed Development, K. Jomo and E. Reinert (eds.), New Delhi, Zed.

Krugman, P. (2011), "Mr Keynes and the moderns", 21 June [online] https://voxeu.org/article/mr-keynesand-moderns.

(2005), "The debt-peonage society", The New York Times, 8 March [online] www.nytimes.com/2005/03/08/ opinion/the-debtpeonage-society.html.

(1994), The Age of Diminished Expectations: U.S. Economic Policy in the 1990s, Cambridge, MIT Press.

Laclau, E. and C. Mouffe (2011), Hegemony and Socialist Strategy: Towards a Radical Democratic Politics, London, Verso.

Lamarca, F. (2009), Las prisas pasan, las cagadas quedan, Santiago, La Tercera Ediciones.

Lawson, T. (2003), Reorienting Economics, Abingdon, Routledge. 
Levi, P. (1986), "Primo Levi's heartbreaking, heroic answers to the most common questions he was asked about 'Survival in Auschwitz'”, The New Republic, 17 February [online] https://newrepublic.com/article/119959/ interview-primo-levi-survival-auschwitz.

Libreria Editrice Vaticana (2015), "Address of his holiness Pope Francis to representatives of the confederation of Italian cooperatives", 28 February [online] http://www.vatican.va/content/francesco/en/speeches/2015/ february/documents/papa-francesco_20150228_confcooperative.html.

Lieberman, E. (2003), Race and Regionalism in the Politics of Taxation in Brazil and South Africa, Cambridge, Cambridge University Press.

López, R. and S. Miller (2008), "Chile: the unbearable burden of inequality", World Development, vol. 36, No. 12, December.

Mazzucato, M. (2018), The Value of Everything: Making and Taking in the Global Economy, London, Allen Lane. (2013), The Entrepreneurial State: Debunking Public vs. Private Sector Myths, London, Anthem Press.

Milanovic, B. (2019), Capitalism, Alone: The Future of the System That Rules the World, Cambridge, Harvard University Press.

(2016), Global Inequality: A New Approach for the Age of Globalization, Cambridge, Harvard University Press.

Ministry of Social Development and Family Affairs (2020), "Encuesta Casen", Observatorio Social [online] http://observatorio.ministeriodesarrollosocial.gob.cl/encuesta-casen.

Mönckeberg, M. O. (2015), El saqueo de los grupos económicos al Estado chileno, Santiago, Debolsillo.

North, D. and others (2007), "Limited access orders in the developing world: a new approach to the problems of development", Policy Research Working Paper, No. 4359, Washington, D.C., World Bank.

Northrop, F. S. (1958), "Introduction”, Physics and Philosophy: The Revolution in Modern Science, W. Heisenberg, Harper Brothers.

Ocampo, J. A. (ed.) (2019), International Policy Rules and Inequality: Implications for Global Economic Governance, New York, Columbia University Press.

OECD (Organization for Economic Cooperation and Development) (2020a), OECD.Stat [online database] https://stats.oecd.org/.

(2020b), "Revenue statistics in Latin America and the Caribbean 2020 - Chile" [online] http://www.oecd. org/tax/tax-policy/revenue-statistics-latin-america-and-caribbean-chile.pdf.

Oliveira, F. de (2003), "The duckbilled platypus", New Left Review, vol. 24, November-December.

Palma, J. G. (2021), "Todo lo que siempre quiso saber sobre el TPP-11 (pero nunca se atrevió a preguntar)", 26 January [online] https://www.ciperchile.cl/2021/01/26/todo-lo-que-siempre-quiso-saber-sobre-el-tpp11-pero-nunca-se-atrevio-a-preguntar/.

(2020a), "América Latina en su "momento gramsciano": las limitaciones de una salida tipo "nueva socialdemocracia europea’ a este impasse”, El Trimestre Económico, vol. 87, No. 348, October-December [online] https://www.eltrimestreeconomico.com.mx/index.php/te/article/view/1146.

(2020b), "Finance as perpetual orgy: how the 'new alchemists' twisted Kindleberger's cycle of 'manias, panics and crashes' into 'manias, panics and renewed manias'”, Cambridge Working Papers in Economics, No. 2094, October.

(2020c), "What went wrong with European social democracy: on building a debilitating capitalism, where even the welfare State subsidises greater market inequality", Amartya Sen Lecture, 2020 Human Development and Capability Association (HDCA) Conference, Auckland, 30 June to 2 July [online] https:// www.youtube.com/watch?v=wY9XFQA-McA\&feature=youtu.be.

(2019a), "Behind the seven veils of inequality: what if it's all about the struggle within just one half of the population over just one half of the national income?", Development and Change, vol. 50, No. 5, September. (2019b), "The Chilean economy since the return to democracy in 1990: on how to get an emerging economy growing, and then sink slowly into the quicksand of a "middle-income trap", Cambridge Working Papers in Economics, No. 1991, University of Cambridge.

(2018), “EI TPP-11, el gobierno saliente y la 'utopía-invertida'”, Centro de Investigación Periodística (CIPER), 9 March [online] https://www.ciperchile.cl/2018/03/09/el-tpp-11-el-gobierno-saliente-y-la-utopia-invertida/. (2016a), "Do nations just get the inequality they deserve? The 'Palma ratio' re-examined”, Inequality and Growth: Patterns and Policy, vol. II, K. Basu and J. Stiglitz (eds.), New York, Palgrave Macmillan.

(2016b), "The dependency school and its aftermath: why Latin America's critical thinking switched from one type of absolute certainties to another", Handbook of Alternative Theories of Economic Development, E. Reinert, J. Ghosh and R. Kattel (eds.), Cheltenham, Edward Elgar. 
(2013), “¿Cuánto habrá que esperar para que los Chicago Boys \& Asociados respondan por el botín que algunos se llevaron?", Centro de Investigación Periodística (CIPER), 12 September [online] https://www. ciperchile.cl/2013/09/12/\%C2\%BFcuanto-habra-que-esperar-para-que-los-chicago-boys-asociadosrespondan-por-el-botin-que-algunos-se-llevaron/.

(2011), "Homogeneous middles vs. heterogeneous tails, and the end of the 'inverted-U': it's all about the share of the rich", Development and Change, vol. 42, No. 1, April.

(1978), "Dependency: a formal theory of underdevelopment or a methodology for the analysis of concrete situations of underdevelopment?", World Development, vol. 6, No. 7-8, July-August.

Parrondo, J. M. (1996), "How to cheat a bad mathematician", Group of Statistical Mechanics at Universidad Complutense de Madrid [online] http://seneca.fis.ucm.es/parr/GAMES/cheat.pdf.

Pérez, C. (2002), Technological Revolutions and Financial Capital: The Dynamics of Bubbles and Golden Ages, Cheltenham, Edward Elgar.

Piketty, T. (2020), Capital and Ideology, Cambridge, Harvard University Press. (2014), Capital in the Twenty-First Century, Cambridge, Harvard University Press.

Poulantzas, N. (1975), Political Power and Social Classes, New York, New Left Books.

Ricardo, D. (1817), On the Principles of Political Economy and Taxation, London, John Murray.

Rowthorn, R. (2014), "A note on Piketty's Capital in the Twenty-First Century", Cambridge Journal of Economics, vol. 38, No. 5, September.

Russell, B. (1959), Common Sense and Nuclear Warfare, George Allen and Unwin.

Sartre, J-P. (2004), Critique of Dialectical Reason, London, Verso Books. (1946), The Flies (Les Mouches) and In Camera (Huis Clos), London, Hamish Hamilton.

Scheidel, W. (2017), The Great Leveler: Violence and the History of Inequality from the Stone Age to the Twenty-First Century, Princeton, Princeton University Press.

Segal, H. (1997), Psychoanalysis, Literature and War: Papers 1972-1995, Abingdon, Routledge.

Shakespeare (n/d), "Act 1. Scene Il", King Lear, The Literature Network [online] http://www.online-literature. com/shakespeare/kinglear/3/.

Smith, A. (1776), An Inquiry into the Nature and Causes of the Wealth of Nations, Edwin Cannan (ed.), Chicago, Chicago University Press.

Solow, R. M. (1956), "A contribution to the theory of economic growth", The Quarterly Journal of Economics, vol. 70, No. 1, February.

Solt, F. (2020), "Measuring income inequality across countries and over time: the Standardized World Income Inequality Database", Social Science Quarterly, vol. 101, No. 3, SWIID version 9.0, October [online] https://fsolt.org/swiid/.

Stein, B. (2006), "In class warfare, guess which class is winning", The New York Times, 26 November [online] https://www.nytimes.com/2006/11/26/business/yourmoney/26every.html.

Stiglitz, J. E. (2012), The Price of Inequality: How Today's Divided Society Endangers Our Future, New York, W. W. Norton.

Taylor, L. (2020), Macroeconomic Inequality from Reagan to Trump: Market Power, Wage Repression, Asset Price Inflation, and Industrial Decline, Studies in New Economic Thinking, Cambridge, Cambridge University Press.

(2014), "The triumph of the rentier? Thomas Piketty vs. Luigi Pasinetti and John Maynard Keynes", International Journal of Political Economy, vol. 43, No. 3.

The Conference Board (2020), "Total Economy Database: key findings" [online] https://www.conferenceboard.org/data/economydatabase/.

Wade, R. (2003), Governing the Market: Economic Theory and the Role of Government in East Asian Industrialization, Princeton, Princeton University Press.

Waissbluth, M. (2020), “Un manifiesto socialdemócrata”, El Mostrador, 24 Julio [online] https://www.elmostrador. cl/destacado/2020/07/24/un-manifiesto-socialdemocrata.

Williamson, J. G. (2009), "Five centuries of Latin American inequality", NBER Working Paper, No. 15305, Cambridge, National Bureau of Economic Research (NBER).

Wood, E. M. (2002), The Origin of Capitalism: A Longer View, London, Verso.

World Bank (2020), World Development Indicators [online] https://datatopics.worldbank.org/world-developmentindicators/.

(2016), Poverty and Shared Prosperity 2016: Taking on Inequality, Washington, D.C.

World Inequality Lab (2020), World Inequality Database [online] http://wid.world/.

Žižek, S. (2008), Violence, New York, Picador. 


\section{Annex A1}

\section{The Latin American "new" left}

In essence (for a more detailed analysis see Palma (2016b)) the key to the capitalist elite's distributional success - aside from de facto political power, effective lobbying power, the ability to solve its own problems of collective action, and shrewd political alliances with the middle strata - has been a capacity to build hegemonic consensuses around its ideology and praxis. The "new" Left is just one of its casualties.

It is partly because of this that in Latin America and many other parts of the world the "new" left is characterized by having concluded (a little too eagerly) that, with current domestic and international parameters, it would not be possible to form alliances with enough support to implement progressive economic agendas.

The history of the South teaches us that such agendas require backing from a substantial majority (everything suggests that simple majorities are insufficient) to be able to take on all the international and domestic forces that are customarily compulsively opposed to them. This constituency is required, for example, for the State to be able to impose discipline on capitalist elites (and sometimes on workers) so as to be able to build an economic agenda that brings high levels of efficiency and low levels of inequality in the sphere of production (such as those found in the Republic of Korea and Taiwan Province of China (see figure A2.2)).

In some cases - such those led by Nelson Mandela in South Africa, Lula da Silva in Brazil, and Patricio Aylwin and Ricardo Lagos in Chile- centre-left coalitions in the South have had clear opportunities to build those alliances and garner that support. However, they forsook their progressive economic agendas too easily and abandoned the economy as the cornerstone of the economic debate. Ultimately, they conceded on almost all the points of the economic and distributional debates. In other words, because the "new" left believed it could not obtain enough power to implement its own economic agenda, it tried to gain power to implement someone else's, but more efficiently and with a human face. It thus sought political power to implement what Francisco de Oliveira (2003) christened an "upside-down hegemony" or what Paulo Arantes (2007) called an "inverted utopia". 40

Throughout Latin America, but especially in Chile and Brazil (and also in South Africa) an "urgent needs" argument was used by the "new" left to justify abandoning its economic and redistributive agenda for "prudent" policies (i.e. policies that were acceptable to the dominant groups in the market).

Ultimately, according to Sartre's (2004) concept of mauvaise foi (bad faith), this was an exercise to deceive others and themselves into believing that transformation of society had become the ultimate unacceptable risk. Thus, a key component of the "new-look" pragmatism was never to say or do anything that could wake the ghosts of the past (see Arantes, 2007).

Reportedly, when Margaret Thatcher was asked what her greatest political achievement was, her answer was clear-cut: transforming the Labour party into the 'New' Labour Party of Blair and Brown. ${ }^{41}$ Pinochet (had it occurred to him) could have said the same about the "new" left in chile. These are good examples of how neoliberals succeeded in "manufacturing consent" as Chomsky describes. The most telling sign of neoliberal success at this, particularly in the economic sphere, as Žižek (2008) reminds us, is when the "new" left started "telling stories of others as if they were one's own".

Part of this strategy was to relay this story, disguised as a "third way", to their base, to the capitalist elite and to international financial markets. This also justified their initial reluctant acceptance of the neoliberal model. What was most amazing about this was how easily this narrative convinced the storytellers themselves.

\footnotetext{
40 For more detail on how the Latin American "new" left has lost its ideological compass, see Palma (2016b).

${ }^{41}$ See [online] https://www.independent.co.uk/news/uk/politics/margaret-thatcher-s-legacy-spilt-milk-new-labour-and-big-bangshe-changed-everything-8564541.html.
} 


\section{Annex A2}

\section{Post-war social democracy vs. the post-Thatcher and -Reagan "Third Way"}

In post-war social democratic thinking, and even before the end of the war (such as in the meeting at Bretton Woods), there was one key idea: the only effective way out of the disaster was "to restructure to reactivate". This same idea is the most relevant to Latin America's current situation (Palma, 2020a). This notion called for new economic and social agendas that were closely interlinked and enhanced by interaction. This symmetry between the two agendas in the post-war period became the hallmark of this strategy, and one of its main strengths. Conversely, asymmetry between the two became the defining trait and greatest weakness of "version 2.0" of this strategy in post-1980s neoliberal Europe. The economic agenda would point in one direction, and the social agenda in the other.

\section{The neoliberal crosscurrents of the 1970 s}

One way to visualize the resurgence of neoliberalism during the 1970s is that the stagflation post-1973 awakened the destructive power of fundamentalism; those who worshipped unfettered market forces had been dreaming of their chance to revenge the success of the Rooseveltian-Keynesian "heresy". What neoliberals truly feared was that that success would destroy belief in free markets, threatening analytical chaos that would destroy understanding and eliminate meaning.

This fear brought destructive instincts into play, since the worst part of the Rooseveltian-Keynesian "heresy" and of structuralism in the periphery was its indisputable success in restructuring and reactivating the post-war world economy, both north and south of the Equator.

Therefore, the real challenge for neoliberals was not to creatively overcome Keynesianism, but to erase it from existence. When the main ideologue of the neoliberal reforms in Brazil was asked about their main aim, he replied that it was to undo 40 years of stupidity, and said that one was either a neoliberal or a "neoidiot" (Revista Veja, 15 April 1998). This idea of undoing stupidities - of multiplying everything by minus 1- was what led these neoliberal reforms to become an exercise in non-creative destruction.

According to the psychoanalyst Ron Britton (1998), there is a direct relationship between expectation of understanding of reality and tolerance of dissent. The higher the expectations (as is often the case in natural sciences), the higher the tolerance of dissent; but if expectations are low, intolerance tends to be high. The post-neoliberal reform economic discipline a paradigmatic example of the latter.

Foucault's (2008) conception of the relationship between power and knowledge, particularly the role of economic discipline in democracy - as a form of power that disciplines by imposing specific forms of knowledge - is helpful in understanding the role of "experts" in all this. In Chile, and around the world, many have become the praetorian guard of neoliberalism. In a recent debate in Chile on withdrawal of $10 \%$ of private pension funds to help households weather the decline in income caused by the pandemic the self-proclaimed "experts" competed among themselves for the most apocalyptic prediction of what would happen if this was passed by parliament. However, since they have been crying wolf for too long, nobody paid much attention. 


\section{The growing asymmetry between the economic and the social agenda in European new social democracy}

The fundamental problem of European new social democracy, unlike its post-war version, is that its new economic agenda has become entirely dissociated from its social agenda (which maintains its traditional format). Its economic agenda indiscriminately absorbed neoliberal economic discourse, while the latter was almost untouched.

In addition, as both agendas remain stuck in the past - one (the social agenda) trying to repeat it, the other (the economic agenda) attempting the opposite (building a future that is the opposite of that past) - they ignore how a new technological revolution and international economic order necessitate creative rethinking of everything. The epitome of this asymmetry is Germany, as clearly reflected in its market distribution.

Figure A2.1

Germany and Chile: market inequality as measured by the Gini index, 1960-2017

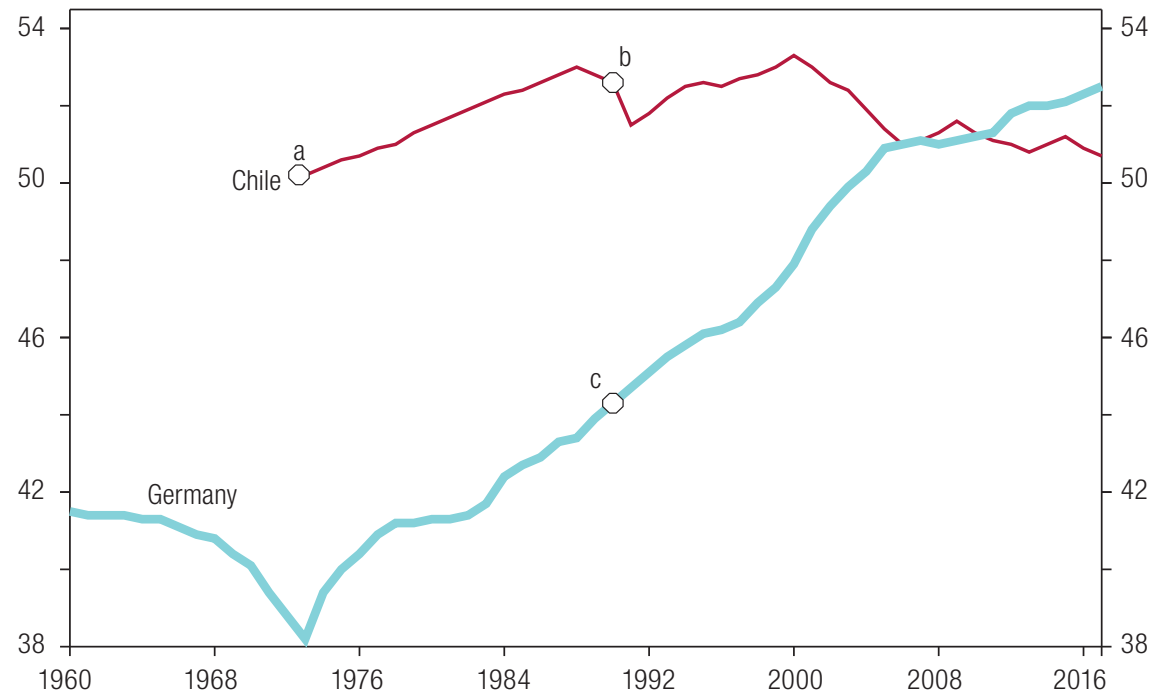

Source: Standardized World Income Inequality Database", October 2020 [online] https://fsolt.org/swiid/.

Note: As the source does not provide information by deciles, it is not possible to perform analysis with the Palma ratio.

a. Pinochet's coup d'état.

b. Chile's return to democracy.

c. German reunification.

It is remarkable how the election of Ronald Reagan and Margaret Thatcher and the fall of the Berlin Wall unleashed in OECD countries a "reverse catch-up" with the highly unequal middle-income countries, such as those in Latin America, "bananizing" their market inequality. The Washington Consensus promised convergence around the world, not just in income, but also in institutions and inequality. Although distributive (and other) convergence did occur, as shown in figure A2.1, it happened in the wrong direction!

The difference between the post-war social democratic economic agenda in Europe and the United States and the subsequent neoliberal one is that the former sought to generate economic dynamism by "disciplining" capital, while the latter ingrained in "common sense" (Gramsci's perspective) that the only way to generate economic growth was by keeping the rich happy. As shown in figure A2.1, this had an unimaginably harmful impact in terms of the inequality of distribution of (pre-tax and pre-transfer) market income. 
Furthermore, while in Germany the market Gini index jumped by a third, investment fell by the same degree, from 30\% of GDP to 20\%, putting it close to the average for Latin America since 1980. This obsession with "Latinamericanizing" investment became widespread in OECD countries. Meanwhile, productivity growth in Germany also collapsed from about 4\%-5\% a year to almost zero, again similar to the Latin American average since 1980 (Palma, 2019a and 2020b).

Thus, in terms of inequality, the new iron law of oligarchy seems to be that with Latin American-style artificially inflated market-inequality, the larger the proportion of income appropriated by the top, the smaller the proportion of that income that is returned to the economy in a productive way. As suggested above, it is tempting to say, "Welcome to the Third World".

The United States also became more unequal in its market distribution than its neighbour on the other side of the Rio Grande (Gini indices of 51 for the United States and 47 for Mexico in 2018). If the United States had its pre-pandemic income level, but the inequality of when Reagan was elected president, the top 1\% would earn US\$ 2 trillion less than they did (more than Brazil's GDP). Meanwhile, the average real hourly wage has been stagnant since the Reagan administration.

In turn, if the United States had the same income and inequality as in 2019, but its share of investment to GDP were as it was pre-Reagan, over US\$ 1 trillion more would be invested per year. Linking the two together (greater inequality with less investment and productivity growth), we find a clear tendency to "bananize", or of "reverse catching up" in motion with countries on the other side of the Rio Grande.

It should be no surprise, then, that when Pope Francis referred to this type of capitalism and its unbridled greed, he said it was the "dung of the devil", which creates a "subtle dictatorship", and also plunders nature. ${ }^{42}$ Also, when speaking about financial markets, he added that "A new, invisible and at times virtual, tyranny is established, one which unilaterally and irremediably imposes its own laws and rules." 43

My main criticism of the European "new" social democracy is not that it became neoliberal (there is no accounting for tastes); instead, it concerns its inability to absorb elements of economic neoliberalism creatively. As mentioned above, for Gramsci (1992) every hegemonic ideology, if it wishes to maintain its position, has to absorb elements of opposing ideologies, interlinking them with the essence of its own ideology. This means that for a consensus to remain hegemonic, dominant groups have to make ideological concessions to subordinate groups, but without endangering their domination. This is what Chile's elite did so well after losing the 1988 plebiscite and the return to democracy, and is trying to do all over again in what this article calls strategy 4 by integrating aspects of the social agenda of the European "new" social democracy (such as the need for social protection) while maintaining its economic agenda of "more of the same" intact.

The most attractive feature of the European "new" social democracy for the elite was the effort to absorb elements of its opposing ideology unimaginatively and in a sometimes opportunistic way, letting the neoliberal economic ideology simply replace its own. The result was an insipid economic ideology, which was totally disjoined with its social agenda.

The crucial point is that Germany's surprising deterioration of market inequality was far from inevitable (or that in the rest of Europe, Western and Eastern). Figure A2.2 compares Germany and the Republic of Korea.

\footnotetext{
${ }^{42}$ See [online] https://edition.cnn.com/2015/07/07/world/pope-mass-ecuador-quito/index.html; see also https://www.theguardian. com/world/2015/jul/10/poor-must-change-new-colonialism-of-economic-order-says-pope-francis.

${ }^{43}$ See [online] https://uk.reuters.com/article/pope-economy/pope-rails-against-dictatorship-of-the-economy-urges-reformidUSL6NODX27N20130516.
} 
Figure A2.2

Germany and Republic of Korea: market inequality and disposable income inequality, 1960-2016
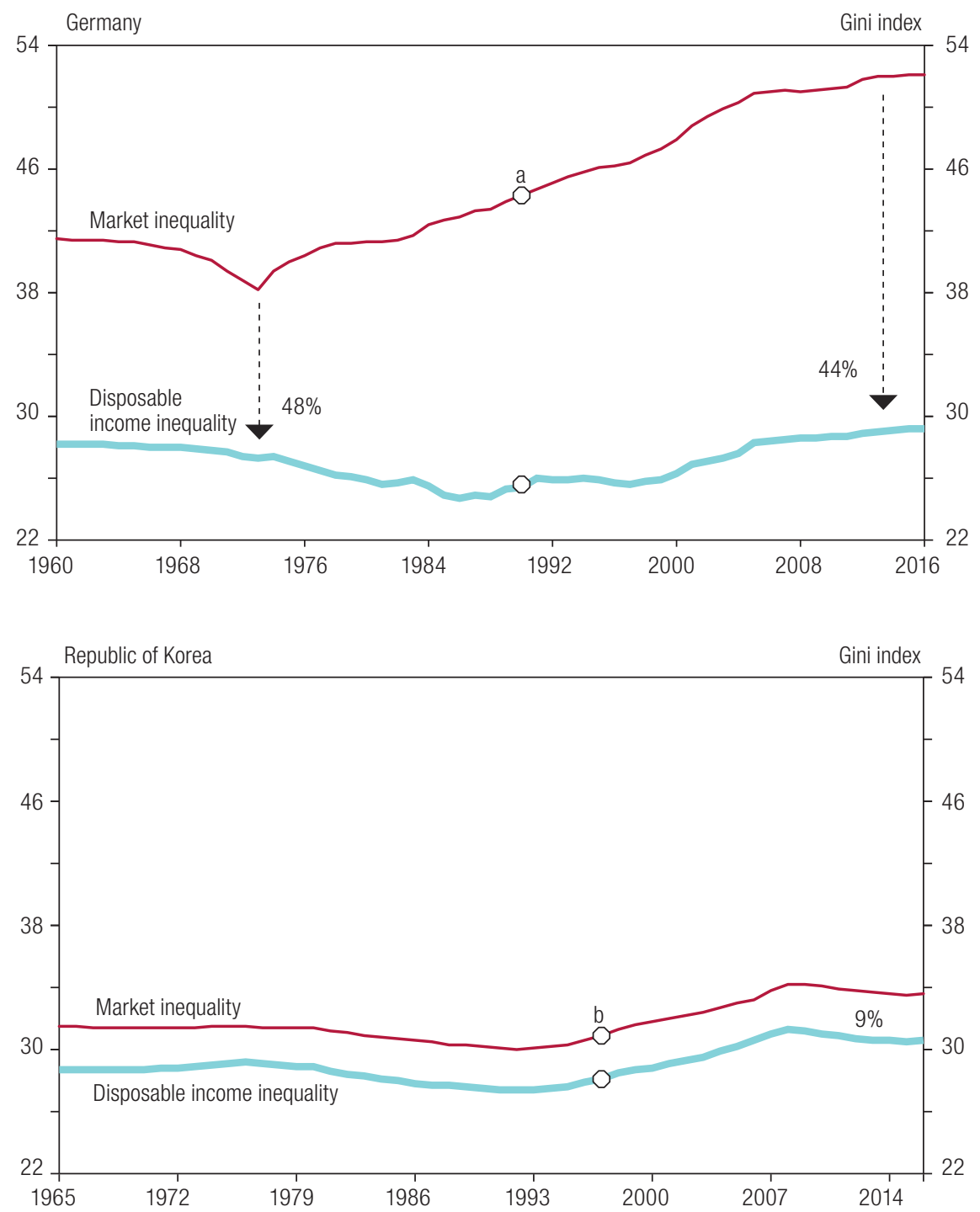

Source:The Standardized World Income Inequality Database", October 2020 [online] https://fsolt.org/swiid/.

Note: a. German reunification.

b. Financial crisis.

As shown in figure A2.2, Germany and the Republic of Korea arrived at a similar distribution of disposable income (a Gini index of around 30, equivalent to a Palma ratio of about 1.2). However, the Republic of Korea almost achieves that low level of disposable income inequality already in the sphere of production. Germany, in contrast, has chosen to follow a tortuous path: while it let its market distribution worsen artificially by 14 percentage points on the Gini index scale between the mid-1970s and the mid-2010s, it then (and as opposed to the Latin American countries) implements a redistributive policy of pharaonic proportions so as to arrive at the same level of disposable income inequality as the Republic of Korea (a country that achieves that low-inequality level without much redistribution effort as it almost arrives there in the market). 
This is what I call European new social democracy's "distributive failure" (Palma, 2019a). Letting things go in one direction in the market, and reverting them through taxes and transfers. This failure is different from a self-built increase in market inequality per se, which is a distributive failure in itself. This new distributive failure relates to the need to make an ever-greater effort to reduce the increasingly distorted market inequality, which absorbs more and more resources and is certainly unsustainable in the long run (Palma, 2019a).

The result of this distributive failure is that the direct requirements for social protection in the European Union already represented $40 \%$ of public spending before the pandemic, or an equivalent of $16 \%$ of GDP. If one adds public health and education, the three areas together accounted for two thirds of all public spending or an equivalent of $25 \%$ of GDP. As a result of the pandemic, as inequality and the need for social protection have increased, this cost has soared. ${ }^{44}$ In the eurozone, for example, the budget deficit has grown almost tenfold to counter the pandemic (Financial Times, 2020b).

In sum, even before the pandemic, in Germany one out of every four euros of value added had to be allocated to the different areas of social protection, mostly to reverse a self-built, unnecessary, inefficient and gigantic market inequality, which was even of a Latin American-style.

Pope Francis hit the nail on the head when he addressed this subject: "Certain liberalism believes it is necessary to first produce wealth" for a given few "no matter how, to then promote some policy of redistribution by the State" (Libreria Editrice Vaticana, 2015). The key here is the "no matter how": Europe has not only "latinamericanized" its market inequality, its increasingly financialized and rentier elite, in doing so, has done the same with investment and productivity growth levels.

The Republic of Korea, meanwhile, only needs to invest $11 \%$ of GDP in social protection to reach the same distribution of disposable income for which Germany has to spend more than double. That is why the Republic of Korea can afford two simultaneous luxuries: collecting 15 percentage points of GDP less in taxes than Germany, and having a level of public investment that is twice that of Germany (OECD, 2020a).

This is why the European new social democratic welfare state has ended up being a de facto subsidy for market inequality, since such high inequality would not be politically feasible without either a stratospheric level of social protection, requiring taxation in the region of $40 \%$ of GDP and an explosion in public debt. Social protection is supposedly a subsidy for the poorest, but in practice high-income groups are some of the greatest beneficiaries, as it allows them to maintain "more of the same".

This is also reflected in the fact that after the 2008 global financial crisis, the United States and Europe spent US\$ 1 trillion on bank bailouts and injected US\$15 trillion via quantitative easing (QE), greatly and artificially increasing the net worth of a handful of individuals (Palma, 2020b). The result, as previously described, is that the welfare state has become a de facto post-modern Robin Hood, who "steals" from the rich to give to the even richer (Palma, 2020c).

44 See Financial Times (2020a) and Palma (2020b). 